\title{
Traditional uses, phytochemistry and pharmacology of Bauhinia racemosa Lam.: a comprehensive review
}

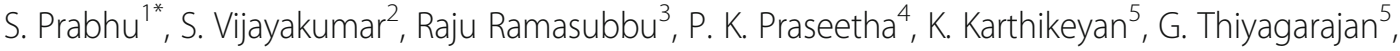 \\ J. Sureshkumar ${ }^{1}$ and N. Prakash ${ }^{6}$
}

\begin{abstract}
Background: Bauhinia racemosa is not familiarly known in Asian countries due to its limited existence and lack of medicinal information. It is commonly used as a medicine, ornamental plant, fence plant, and fodder for livestock since ancient times. It is also used as a landfill tree to avoid soil erosion of the forest.

Main body: In South India, people cultivate this plant in their premises in order to protect themselves from the effects of thunder. In this review, the various research prospects of this plant have been analyzed and are summarized. The aim of this review is to provide the traditional uses, phytochemicals and pharmacological activities of $B$. racemosa, and to highlight the current pharmacological developments of this medicinal plant.

Conclusions: The B. racemosa has immense therapeutic potential for treating diseases with both traditional and pharmacological applications. But many traditional uses of $B$. racemosa have not been validated by current investigations in the aspects of pharmaceutical. Until now, research on phyto-constituents from $B$. racemosa has not been done in an extensive way. Hence, the identified phytochemicals of $B$. racemosa should also be subjected to pharmacological studies to illuminate the biological mechanisms of these unreported secondary metabolites for the prevention of diseases or microbial infections and other health disorders of human and animal races.
\end{abstract}

Keywords: Bauhinia racemosa, Traditional uses, Phyto-chemistry, Pharmacognosy, Tablet binder, Masanumas 2

\section{Background}

Bauhinia racemosa Lam is a small, crooked, bushy, deciduous tree that can grow under very difficult climatic environments with drooping branches. This species is commonly found across India, which grows in the western Himalayas, in Ceylon, China, and Timor, to an altitude of $1650 \mathrm{~m}$ from sea level. It is widely used to fill blank areas of the forest land, since it prevents soil erosion. The matured leaves of $B$. racemosa are used for making Beedi (Indian cigarettes), whereas the young leaves are used as greens (side dish) by the Tamilians (Tamil Nadu, India). The bark and leaves of

\footnotetext{
* Correspondence: prabhusbotany@gmail.com

'Department of Botany, Annai Vailankanni Arts and Science College (Affiliated to Bharathidasan University, Trichy-24), Bishop Sundaram Campus, Pudukkottai Road, Thanjavur 613007, Tamil Nadu, India

Full list of author information is available at the end of the article
}

B. racemosa are sweetish and acrid, used as a refrigerant, astringent, in the treatment of headache, fever, skin diseases, blood diseases, dysentery, and diarrhea. A decoction of the bark is recommended as a useful wash for ulcers [1].

In ayurveda, the plant is commonly used for the treatment of initial stage of cancer [2,3]. A large number of studies have confirmed that $B$. racemosa has a wide range of pharmacological effects, including antitumor activity, anti-inflammatory activity, analgesic effect, antipyretic, antihyper-glycemic activity, hepato-protective activity, antimicrobial activities, antiulcer activity, antihistaminic effect, anxiolytic activity, and anti-HIV activity [1]. The medical value of this plant attracts more attention of the people due to the complications of health issues. With the advent of chemical composition and pharmacological research, the clinical application of Bauhinia racemosa has been 
expanded. In addition, this plant product is cheap and widely available on earth, which has useful clinical applications and drug development prospects as well.

Hence, a growing number of researchers have dedicated their spare time to this wonderful plant in the last few decades, from botany to phytochemistry and pharmacology. The phytochemical studies have identified more than 37 chemicals from B. racemosa, including Phenolics, Flavonoids, Saponins, Glycosides, Terpenoids, Steroids, Propanoids, Coumarin, lipids, Alkaloids, and Tannins [4]. However, minimal numbers of articles have reviewed the comprehensive research of $B$. racemosa. The available record reveals that there is only a concise review of its phytochemistry and pharmacology, which may not be enough for researchers to completely understand this plant. Researchers have identified several new chemical components from $B$. racemosa and should perform more indepth analyses of its pharmacological activities. This paper reviews the traditional uses, botany, phytochemistry, and pharmacological characteristics of B. racemos $a$ in a precise form that helps to recognize readers to a stronger and deeper understanding of this medicinal plant and also provide thorough information for better research and development of $B$. racemosa. The extracts of leaves and bark have shown analgesic, anti-pyretic, antimicrobial, antiinflammatory, anti-spasmodic, and anti-helmintic efficacy.

In South India, the plant is traditionally known as idithangi, aaththi maram, and thathagi. It is also called Banraj in Bengali, Kachnal in Hindi, Aapta in Kannada, Kosundra in Punjabi, Arampaali in Malayalam, Asundro in Gujrati, Sona in Marathi, Yugmapatra in Sanskrit, Arechettu in Telugu, and Kachnaar in Unani around various parts of India.

Taxonomic treatment [5]

\begin{tabular}{ll}
\hline Kingdom: & Plantae \\
Clade: & Tracheophytes \\
Clade: & Angiosperms \\
Clade: & Eudicots \\
Clade: & Rosids \\
Order: & Fabales \\
Family: & Fabaceae \\
Subfamily: & Cercidoideae \\
Tribe: & Bauhinieae \\
Genus: & Bauhinia \\
Species & racemosa Lam. \\
\hline
\end{tabular}

Synonyms

Bauhinia parviflora Vahl

Piliostigma racemosa (Lam.) Benth.

Piliostigma racemosum

\section{Main text}

Method and direction of data collection

Information on the traditional uses of $B$. racemosa has been collected from ethnobotanical documentation and was gathered from few online web portals, including www.flowersofindia.net, efloraofindia, http:// senthuherbals.blogspot.com, and http://www.bsienvis. nic.in/. To highlight the traditional uses of $B$. racemosa in Tamil Nadu, we searched using a variety of Tamil words, such as thathagi, Aaththi Maram, and idithangi. In this review, we have scrutinized the known ethnobotanical uses, phytochemicals, pharmacological potentials, and fodder necessity of $B$. racemosa. We retrieved the research and review articles from Science Direct, PubMed, and other international publications using the keywords ethnobotany, phytochemistry, and pharmacology along with the name of B. racemosa. An online database http://www.theplantlist.org was used to confirm its botanical name. KEGG software was used for analyzing the pathway of human acid secretion and type-II diabetes mellitus.

\section{Ethnobotanical uses and nutritional values}

B. racemosa has been used for medicinal purposes since ancient times; hence, it has a long history with therapeutic purposes in South India. Parts of this plant, such as whole, stem bark, leaves, and bark, are used for diabetes, stomach pain, piles, and intestinal ulcers by different ethnic groups in South India. In addition, parts of the plant are documented as traditional medicines for dysentery, diarrhea, malaria, influenza, epilepsy, vomiting, edema, constipation, gastric, dyspepsia, and convalescents in various parts of India. These ethnobotanical uses have been documented with the help of various ethnic people (Table 1). In addition, it has abundant protein values; hence, the leaves of $B$. racemosa are also given as fodder for animals to secrete more quantities of milk. We can give up to 4 to $5 \mathrm{~kg}$ of leaves for cow and $11 / 2$ to $2 \mathrm{~kg}$ for a goat. Leaves and seeds consist of $8.9 \pm 0.88$ and $0.63 \pm 0.98 \%$ of proteins respectively.

\section{Ayurvedic mixtures of $B$. racemosa (in market)}

Masanuma 2 is a blend of plant combinations (extracts of different plant parts). In the second month of pregnancy, it is advised the mother to prevent regular abortions, high-risk pregnancies, and improve high-value pregnancy. Each bottle consists of 120 tabs with a weight of $60 \mathrm{mg}$ (each tablet). Each tablet contains B. racemosa stem bark, Sesamum indicum seed extracts, Rubia cordifolia stem extracts, and Asparagus racemosus root extracts respectively. This tablet was administered twice a day for lunch and dinner with two tablets each (anonymous). 
Table 1 Traditional uses of $B$. racemosa

\begin{tabular}{|c|c|c|c|}
\hline Year of report & Recommended parts & Traditional uses & References \\
\hline \multirow[t]{2}{*}{1935} & Bark fiber & Wound stitching material & [6] \\
\hline & Bark & leprosy and leucoderma & \\
\hline 1956 & Leaves & Urinary diseases & [7] \\
\hline 1982 & Stem bark & Glandular inflammation & [8] \\
\hline 1996 & Root and bark & Epilepsy & [9] \\
\hline 1998 & Root and bark & Epilepsy & [10] \\
\hline 1998 & Gum & Brain tumors & \\
\hline 2007 & Stem bark & Abdominal Pain & [11] \\
\hline 2013 & Stem bark & Dysentery and diarrhea & [12] \\
\hline 2015 & Leaves & Mouth ulcer & [13] \\
\hline 2016 & Whole plant & Anti-diabetes & [14] \\
\hline 2016 & Stem bark & Intestinal Ulcer & [15] \\
\hline 2016 & Stem bark & Dysentery and diarrhea & [16] \\
\hline 2016 & Leaves & Piles & [15] \\
\hline 2018 & Fruit & Diarrhea and vomiting & [17] \\
\hline 2019 & Not specified & Malaria, fever and Piles & [18] \\
\hline \multirow[t]{2}{*}{2019} & Flower & Cold and cough & [19] \\
\hline & Root & Stomach ache & \\
\hline 2019 & Leaves & Head ache and malaria & [20] \\
\hline
\end{tabular}

\section{Tablet binder}

Seed resins of $B$. racemosa are tested as tablet binder by Gangurde and Boraste [21]. In their tablet binder experiments, the seed mucilage has shown optimal results at $8 \% \mathrm{w} / \mathrm{w}$ concentration among the established formulations. They have also stated that seed resins are found to be as a better tablet binder and granulating agent in the wet granulation process [21].

\section{Phytochemistry}

The exploration and separation of phyto-constituents are very important in order to discover the possibilities for the treatment of diseases. Only a few studies have been undertaken relating to the phytoconstituents of $B$. racemosa. To date, over 37 compounds have been isolated from various parts of this plant and identified. In this review, phytoconstituents in B. racemosa are comprehensively reported, including alkaloids, steroids, triterpenoids, glycosides, tannins, saponins, phenolic compounds, flavonoids, galactolipid, catechin, and others $[22,23]$. The identified phytochemicals of $B$. racemosa have been described in Table 2 and Fig. 1. Phytochemicals whose biological processes have not been recorded should not be ignored, and such phytoconstituents should be subject to different experiments until their biological activities have been detected. Phytoconstituents can vary from different parts of plants; hence, a thorough study should be needed to find a novel drug and to conserve the plant. Several scientific studies also have suggested that some flavonoids, triterpenoids, and steroids have a protective potential on the liver owing to their antioxidant effects [34-36]. Due to the presence of these compounds in methanolic extracts of $B$. racemosa (MEBR), it may play significant preventive measures in the liver damage caused by synthetic drugs.

Similar phyto-compounds of $B$. racemosa such as Mome inositol (Cyamopsis tetragonoloba), Neophytadiene, Resveratrol (Arachis hypogaea, Vitis vinifera), Lupeol (Alstonia scholaris), Octacosane, $\beta$-sitosterol (Clerodendrum infortunatum, Alstonia scholaris), $\beta$ amyrin (Alstonia boonei, Alstonia scholaris), Racemosol, Galactolipid (Phyllanthus embilica), Catechin (Phyllanthus embilica), Betulin (Alstonia scholaris), Quercetin (Phyllanthus embilica, Allium sativum), Rutin (Ginkgo biloba, Lycopersicon esculentum), and Kaempferol (Mangifera indica, Allium sativum) are found in many plants which are having broad of pharmacological properties.

\section{Pharmacological descriptions of the metabolites and its market price}

The secondary metabolites of $B$. racemosa such as $\beta$ sitosterol, $\beta$-amyrin, kaempferol, rutin, quercetin, catechin, eicosanoic acid, -epiafzelechin, -epicatechin, protocatechuic acid, octacosanol, scopoletin, and scopolin are also found in other medicinal plants as well. Previous studies have indicated that such molecules have a wide 
Table 2 Phytoconstituents of B. racemosa that have been extracted by different solvents

\begin{tabular}{|c|c|c|c|c|c|}
\hline $\begin{array}{l}\text { S. } \\
\text { No. }\end{array}$ & Phyto-constituents & $\begin{array}{l}\text { Compound } \\
\text { category }\end{array}$ & Source & Solvent & References \\
\hline 1. & $\begin{array}{l}\text { (2S)-1,2-di-O-linolenoyl-3-O-a-Galactopyranosyl ( } 1 \rightarrow 6)-\mathrm{O}-\beta \text { - } \\
\text { galactopyranosyl glycerol }\end{array}$ & Alakloids & Leaves & Ethanol & [24] \\
\hline 2. & $\begin{array}{l}\text { (2S)-1-O-linolenoyl-2-O-palmitoyl-3-O-a-galactopyranosyl ( } 1 \rightarrow 6)-O-\beta- \\
\text { galactopyranosyl glycerol }\end{array}$ & Alkaloids & Leaves & Ethanol & [24] \\
\hline 3. & $\begin{array}{l}\text { (2S)-1-O-oleoyl-2-O-palmitoyl-3-O-a-Galactopyranosyl ( } 1 \rightarrow 6)-\mathrm{O}-\beta \text { - } \\
\text { galactopyranosyl glycerol }\end{array}$ & Alkaloids & Leaves & Ethanol & [24] \\
\hline 4. & 4-Notrophenol & Alkaloids & Leaves & Ethanol & [4] \\
\hline 5. & Epiaflechin & Flavonoids & Leaves & Ethanol & [25] \\
\hline 6. & Pacharin & Flavonoids & $\begin{array}{l}\text { Heart } \\
\text { wood }\end{array}$ & Acetone & {$[23,26,27]$} \\
\hline 7. & (+)-Epicatechin & Flavonoids & Leaves & Ethanol & [25] \\
\hline 8. & Bauhinoxepin F & Flavonoids & & & \\
\hline 9. & $\begin{array}{l}\text { 2-methoxy-6,6,8-trimethyl-5,6,1 1,12-tetrahydro-4bH-benzo[6, } \\
\text { 7]cyclohepta[1,2,3-de]chromene-1,9-diol }\end{array}$ & Flavonoids & & & \\
\hline 10. & $\begin{array}{l}\text { (Aflatoxin B1) 6,6,8-trimethyl-5,6,11,12-tetrahydro-4bH-benzo[6, } \\
\text { 7]cyclohepta[1,2,3-de]chromene-1,2,9-triol }\end{array}$ & Flavonoids & & & \\
\hline 11. & 6-octen-1-ol,3,7-dimethyl-,propanoate & Flavonoids & Leaves & Ethanol & [28] \\
\hline 12. & Citronellyl butyrate & Flavonoids & Leaves & Ethanol & {$[28]$} \\
\hline 13. & De-O-methylracemosol & Flavonoids & $\begin{array}{l}\text { Heart } \\
\text { wood }\end{array}$ & Hexane & [29] \\
\hline 14. & Kaemferol & Flavonoids & Aerial part & $\begin{array}{l}\text { Dichloromethane: ethyl } \\
\text { acetate }(95: 5)\end{array}$ & {$[30]$} \\
\hline 15. & Quercetin & Flavonoids & Aerial part & $\begin{array}{l}\text { Ethyl acetate: methanol } \\
(60: 40)\end{array}$ & [30] \\
\hline 16. & Kaempferol 3-O- $\beta$-glucoside & Flavonoids & Aerial part & Ethyl acetate & {$[30]$} \\
\hline 17. & Myricetin 3-O- $\beta$-glucoside & Flavonoids & Aerial part & $\begin{array}{l}\text { Ethyl acetate: methanol } \\
(60: 40)\end{array}$ & [30] \\
\hline 18. & Quercetin 3-O-rhamnoside & Flavonoids & Aerial part & Ethyl acetate & {$[30]$} \\
\hline 19. & Methyl gallate & Tannins & Aerial part & $\begin{array}{l}\text { Dichloromethane: ethyl } \\
\text { acetate (60:40) }\end{array}$ & {$[30]$} \\
\hline 20. & Gallic acid & Tannins & Aerial part & $\begin{array}{l}\text { Dichloromethane: ethyl } \\
\text { acetate }(90: 10)\end{array}$ & {$[30]$} \\
\hline 21. & Neophytadiene & Terpenoids & Leaves & Ethanol & {$[28]$} \\
\hline 22. & Racemosol & Terpenoids & $\begin{array}{l}\text { Heart } \\
\text { wood }\end{array}$ & Hexane & [29] \\
\hline 23. & Pacharin & Terpenoids & $\begin{array}{l}\text { Heart } \\
\text { wood }\end{array}$ & Acetone & {$[23,26,27]$} \\
\hline 24. & Lupeol & Terpenoids & Root & Benzene & [31] \\
\hline 25. & B-sitosterol & Terpenoids & Stem bark & Petroleum ether & [22] \\
\hline 26. & $\beta$-amyrin & Terpenoids & $\begin{array}{l}\text { Flower } \\
\text { bud }\end{array}$ & $\begin{array}{l}\text { Toluene : ethyl acetate } \\
(93: 07)\end{array}$ & {$[32]$} \\
\hline 27. & Protocatechuic acid & Phenols & Leaves & Ethanol & [25] \\
\hline 28. & Resveratrol & Phenols & Heartwood & Data not available & [33] \\
\hline 29. & Phenol,2,4-bis (1,1-dimethylethyl) & Phenols & Leaves & Ethanol & [28] \\
\hline 30. & Epicatechin & Phenols & Leaves & Ethanol & [25] \\
\hline 31. & Octacosyl ferulate & Propanoids & Leaves & Ethanol & {$[28]$} \\
\hline 32. & Hexacosan-1-ol & Lipids & & & \\
\hline 33. & Octacosanol & Lipids & Stem bark & Petroleum ether & [22] \\
\hline 34. & 16-heptadecenal & Lipids & Leaves & Ethanol & {$[28]$} \\
\hline
\end{tabular}


Table 2 Phytoconstituents of B. racemosa that have been extracted by different solvents (Continued)

\begin{tabular}{|c|c|c|c|c|c|}
\hline $\begin{array}{l}\text { S. } \\
\text { No. }\end{array}$ & Phyto-constituents & $\begin{array}{l}\text { Compound } \\
\text { category }\end{array}$ & Source & Solvent & References \\
\hline 35. & Octacosan & Lipids & Stem bark & Petroleum ether & [22] \\
\hline 36. & Myo-Inositol & Steroids & Leaves & Ethanol & [28] \\
\hline 37. & a-amyrin & Steroids & Stem bark & Petroleum ether & [22] \\
\hline 38. & Scopoletin & Coumarin & Leaves & Methanol & [23] \\
\hline 39. & Scopolin & Coumarin & Leaves & Methanol & [23] \\
\hline
\end{tabular}

range of pharmacological potential for human health complications (Table 3). Due to the pharmacological properties of these compounds, they are marketed at as high prices in the market as seen in Table 4. These compounds are naturally present in medicinal plants like $B$. racemosa. We can take those comprising metabolites as food or decoction, even though we cannot consume them directly. If so, we can avoid the expenses and ignore the adverse effects as well.

\section{Pharmacology}

In recent years, pharmacological activities of crude extracts and metabolites of $B$. racemosa have been investigated as rich essential metabolites that make it a good microbicidal agent. Meanwhile, based on in vivo and in vitro experiments, the extracts of $B$. racemosa also promising stores of possible pharmacological effects such as anti-oxidant, antihistaminic, analgesic, antipyretic, anti-ulcer, anti-cancer, hepatoprotective, antidiabetic, anti-HIV, and larvicidal activities.

Traditional uses in the treatment of asthma, gastrointestinal pain, piles, urinary diseases, glandular inflammation, dysentery, diarrhea, malaria, pneumonia, epilepsy, dehydration, edema, constipation, gastric dyspepsia, and convalescents have not yet been deeply studied. Also, the phytochemicals of $B$. racemosa are not yet studied. We, therefore, recommend that future studies should be based on verifying its traditional significance by advanced pharmacological research. In addition, the screening of the principal bioactive compounds and the mode of action has to be examined. Pharmacological actions of $B$. racemosa are defined in detail in the following sections.

\section{Anti-bacterial and anti-fungal activities}

Invasive fungal infections in the recent times have proven to be mortal, specifically in immune compromised patients $[61,62]$. In addition, the number of animal or plant diseases caused by bacterial, fungal, and microbial infections is increasing. There is an urgent need to develop a new class of antimicrobial drugs and antibiotic substitutes to address this problem. In the foremost antimicrobial research of B. racemosa, Ali et al. [63] proved that the methanolic $(\mathrm{MeOH})$ extracts of phenolic compounds reveals potent inhibitory activities against Salmonella typhi (96.64\%), Shigella boydii (80.55\%), and Staphylococcus pyogenes $(81.12 \%)$, whereas the hexane extracts of that compounds exhibited possible inhibitory activity against Staphylococcus aureus (72.51). Similar to antibacterial test, they have analyzed the antifungal competency against 11 fungal strains by using methanol and hexane extracts of $B$. racemosa. Among the two extracts, the hexane extracts have shown excellent inhibitory activity against Trichophyton longifuses (71.04\%) and Pseudallescheria boydii (83.80\%), while the $\mathrm{MeOH}$ extracts have recorded better inhibitory ratio against Microsporum canis, Trichophyton simii, and Trichophyton schoenleinii with the percentage of 98.44, 95.59, and 81.38. Furthermore, the various extracts of $B$. racemosa were tested on enteric pathogens such as Proteus vulgaris, Staphylococcus epidermidis, Staphylococcus aureus, Escherichia coli, Pseudomonas aeruginosa, Klebsiella pneumonea, Salmonella typhi, Enterobacter aerogenes, and Salmonella typhimurium [64]. Ultimately, the petroleum ether extracts reveals better inhibitory activity against $S$. epidermidis, $S$. aureus, and S. typhi. Following this, the chloroform extract has shown inhibitory action in opposition to $S$. epidermidis and $S$. aureus. Extracts of methanol has exposed maximum inhibitory proportion against $S$. epidermidis, S. aureus, E. coli, $P$. aeruginosa, $E$. aerogenes, and S. typhimurium. In addition, the extract of ethyl acetate has revealed maximum inhibitory activity against $S$. aureus, $P$. vulgaris, $S$. epidermidis, $P$. aeruginosa, S. typhi, and S. typhimurium. Dahikar et al. [64] reported that B. racemosa is having huge potential as antibacterial compounds against enteric pathogens and it can be used as alternative drugs for the diseases of enteric pathogens. Through this review, we suggest that further pharmacological studies are required to develop a new class of antibacterial drugs against enteric pathogens. Because, the enteric or diarrheal infections produce serious health complications of human being in developing nations, which leads to the death of 3.3 to 6.0 million children each year. Also, the infectious strains are harmful etiological agents in causing intermittent and continuous diarrhea in both children and adults [65]. Another antimicrobial approach 


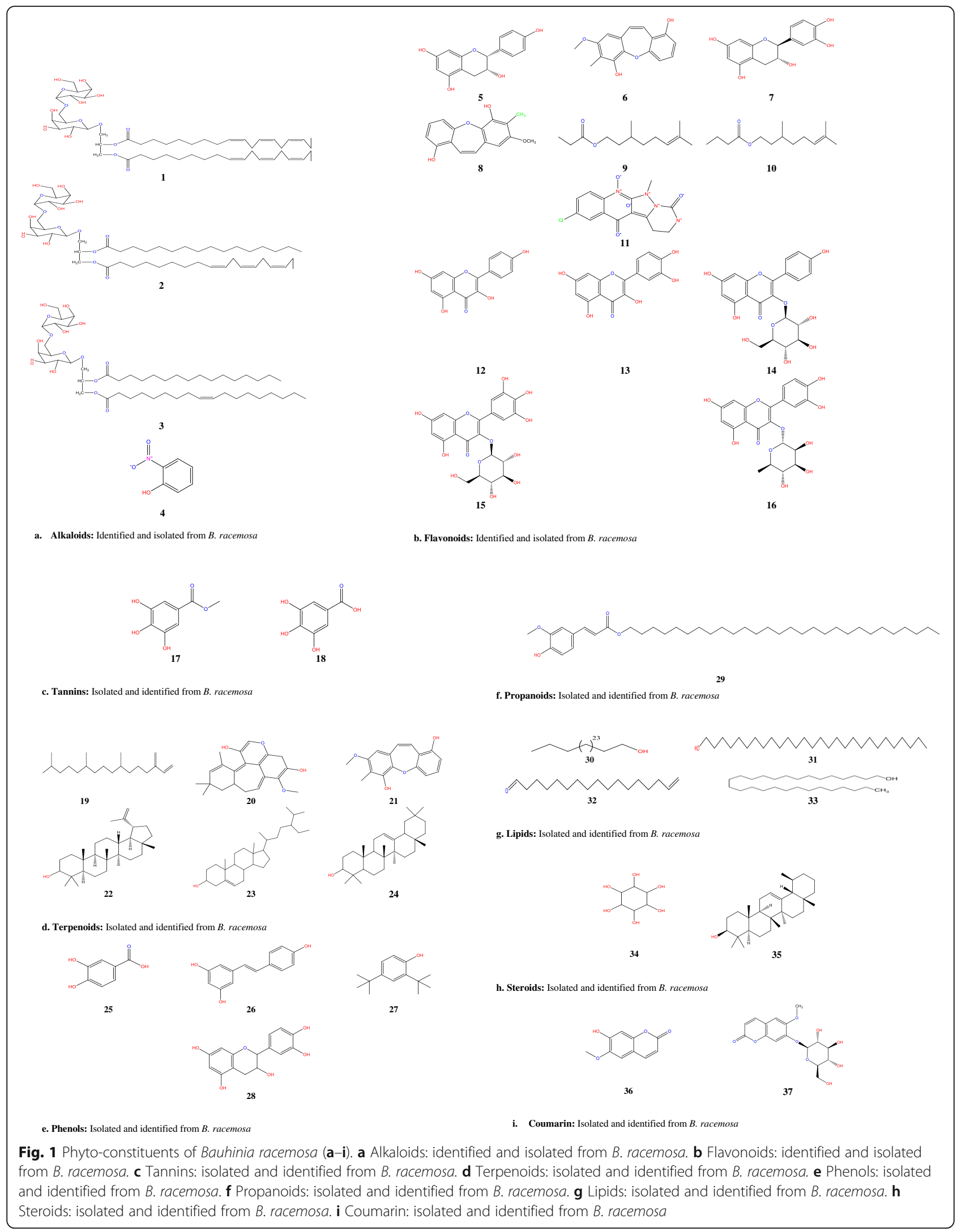


Table 3 Similar molecules and their prices in the market

\begin{tabular}{lllll}
\hline S. No. & Compound Name & CAS No. & Available dose & Cost (INR) \\
\hline 1. & Resveratrol & $501-36-0$ & $100 \mathrm{mg}$ & $11,532.82$ \\
& & & $500 \mathrm{mg}$ & $45,709.50$ \\
2. & Lupeol & $545-47-1$ & $25 \mathrm{mg}$ & $11,643.87$ \\
& & $100 \mathrm{mg}$ & $32,646.11$ \\
3. & B-Sitosterol & $83-46-5$ & $10 \mathrm{mg}$ & $15,840.05$ \\
& & & $25 \mathrm{mg}$ & $31,600.09$ \\
& & $100 \mathrm{mg}$ & $87,130.26$ \\
4. & B-amyrin & $559-70-6$ & $10 \mathrm{mg}$ & $46,631.40$ \\
5. & Kaempferol & $520-18-3$ & $25 \mathrm{mg}$ & $10,977.87$ \\
& & & $100 \mathrm{mg}$ & $35,930.59$ \\
6. & Scopolin & $531-44-2$ & $10 \mathrm{mg}$ & $32,855.92$ \\
\hline
\end{tabular}

exposed that the acetone and ethanol extracts demonstrated potent inhibitory action against all the tested strains than that of aqueous, chloroform, and petroleum ether [66], but this study lacked the comparative analysis with the commercial drugs (positive control) of enteric pathogens. In addition, no positive control drug was used during the experiments, making it difficult for other researchers to mimic the study and compare the results. Later, a study in 2005 revealed that the methanolic extract of $B$. racemosa stem bark had notable antimicrobial activities against Pseudomonas aeruginosa, Escherichia coli, Salmonella typhi, Shigella dysenteriae, Vibrio cholera, Staphylococcus aureus, Streptococcus pneumonea, Micrococcus luteus, Staphylococcus epidermidis, Candida albicans, Aspergillus niger, Aspergillus flavus, and Alternaria solani at various concentrations. The various MEBR concentrations are 25, 50,100 , and $200 \mu \mathrm{g} / \mathrm{disc}$. Besides this, according to Heinrich et al. [67], the quality of concentration should also be pharmacologically important. The concentration used by Chaimanee et al. [68] became much higher, having no benefit from a clinical perspective. To evaluate their effects on a wider variety of microbial strains, further formulations of the customized extracts are required. Though its reliability of earlier studies has been confirmed, more in-depth experiments are needed in the studies performed. The nature and quantity of the bioactive constituents in the extract are not apparent.

Table 4 Pharmacological applications of those identified molecules

\begin{tabular}{|c|c|c|c|}
\hline $\begin{array}{l}\text { S. } \\
\text { No. }\end{array}$ & $\begin{array}{l}\text { Phyto- } \\
\text { compounds }\end{array}$ & Biological activity & References \\
\hline \multirow[t]{2}{*}{1} & Mome inositol & Anti-proliferative & [37] \\
\hline & & Antialopecic, anticirrhotic, antineuropathic, cholesterolytic and lipotropic activity & {$[38]$} \\
\hline 2 & Neophytadiene & Carminative, Gastrin inhibitor, Antiulcerative, Antiprotozoal, antiparasitic & [39] \\
\hline 3 & Resveratrol & Anti-inlammatory, neuroprotective, antiviral properties & {$[40]$} \\
\hline 4. & Lupeol & $\begin{array}{l}\text { Anti-inflammatory, anti-microbial, anti-protozoal, anti-proliferative, anti-invasive, anti-angiogenic and cholesterol- } \\
\text { lowering agent }\end{array}$ & {$[41]$} \\
\hline 5. & Octacosane & Anti-bacterial & {$[42]$} \\
\hline 6. & $\beta$-sitosterol & $\begin{array}{l}\text { Anti-diabetic activity, Anxiolytic, sedative effects, Analgesic, anti- inflammatory, immunomodulatory, Antibacterial, } \\
\text { Anti-cancer, Anti-inflammatory, Protect against NAFLD, Lipid lowering effect, Hepatoprotective, Protective effect } \\
\text { on Pulmonary fibrosis, Wound healing effect, Antioxidant and Antidiabetic }\end{array}$ & {$[43]$} \\
\hline 7. & $\beta$-amyrin & $\begin{array}{l}\text { Anti-bacterial activity, anti-inflammatory, antinociceptive, antioxidant, antipruritic, gastroprotective, liver injury, he- } \\
\text { patoprotective, Antihyperglycemic and hypolipidemic }\end{array}$ & {$[44-51]$} \\
\hline 8. & Racemosol & Anti-bacterial activity, Acetylcholine sterase inhibitory & {$[52]$} \\
\hline 9. & Galactolipid & $\begin{array}{l}\text { Anti-aggregators, decrease of vascular tone and blood pressure, and hence may prevent the development of } \\
\text { cardiovascular diseases, reduce deaths and suddencardiac arrest, preventing obesity and Type } 2 \text { diabetes, } \\
\text { reduced risk of cancer, control stress such as mental and nutrient stress, }\end{array}$ & {$[53,54]$} \\
\hline 10 & Catechin & Anti-inflammatory, antioxidant, anti-tumor, and hepato-protective bioflavonoid & [55] \\
\hline 11. & Betulin & Anti-inflammatory, Anti-bacterial activity & [56] \\
\hline 12. & Quercetin & $\begin{array}{l}\text { Antioxidant, Allergy asthma, atopic diseases, Cardiovascular diseases, cancer, Diabetes, Alzheimer, Huntington, } \\
\text { parkinsonism, sleep, Obesity, anticancer potential against prostate cancer }\end{array}$ & {$[57,58]$} \\
\hline 13. & Rutin & $\begin{array}{l}\text { Analgesic, antinociceptive, Antiarthritic, Anti-diabetic, Anti-hypercholesterolemic, Thyroid uptake promotion, Car- } \\
\text { diovascular system, Hypertension, Blood coagulation, Anti-platelet aggregatory, Antiulcer, Anti-asthmatic, Anti- } \\
\text { osteoporotic, anti-osteopenic, Anti-cataract, ophthalmic, Diuretic, improve quality of sperm and male reproduct- } \\
\text { ive organs, Chemotherapeutic, Antibacterial, Antifungal, Anti-mycobacterial, Larvicidal, Anti-malarial, Antiretroviral, } \\
\text { Antiviral, Sunscreen effects, atopic dermatitis, Immune effects, Body strength, Anti fatigue, Organ protective ef- } \\
\text { fects,Neuro-protective activity, Retino-protective, Protective effect on lung tissue, Cardio-protective, Prevention of } \\
\text { splenocyte apoptosis, Hepato-protective activity, Nephro-protective activity, Protective effect on blood } \\
\text { vasculature }\end{array}$ & [59] \\
\hline 14. & Kaempferol & Apoptosis and growth inhibition, Energetic Impairment, angiogenesis, metastasis, inflammation, anticarcinogenic & {$[60]$} \\
\hline
\end{tabular}




\section{Anti-inflammatory activity}

Inflammation is a complicated, protective response of the host to any external stimuli. Experimental analysis on inflammatory pathways have demonstrated that inflammation can be tackled by controlling the signaling pathways including nuclear factor kappa light chain enhancer (NF-kB), inducible nitric oxide synthase (iNOS), tumor necrosis factor alpha (TNF- $\alpha$ ), cyclooxygenase-2 (COX-2), and interleukin-6 (IL-6) [69]. Bauhinia racemosa is a natural source used to control inflammation due to its anti-inflammatory potential. The inflammatory activity of Wistar albino rats is studied by using the methanolic extracts of B. racemosa in 2005 by Gupta et al. [70]. For inducing acute paw edema, carrageenan, dextran, and mediators such as histamine and serotonin are administered to rats at different doses of 50, 100, and $200 \mathrm{mg} / \mathrm{kg}$ b.w. For evaluating the antiinflammatory potential of $B$. racemosa, the extracts are mixed with ethanol solvent and served inflammation agents subjected to animals at doses of 50, 100, and 200 mg. In their experiment, the indomethacin is used as a standard drug. The prepared extracts at a dose of 200 $\mathrm{mg} / \mathrm{kg}$ shows significant anti-inflammatory effects in edema-induced animals, which is near to the prevention value of indomethacin. The inflammatory ranges are $44.8 \%$ in $200 \mathrm{mg}$ of B. racemosa and $51.5 \%$ in $10 \mathrm{mg}$ of indomethacin. The MEBR has therefore been reported by Gupta et al. [70] to have possible anti-inflammatory potential against acute and chronic inflammation effects.

\section{Antioxidant effects}

The formation of reactive oxygen species (ROS) in the organism would lead to an oxidative stress reaction. In various pathophysiological conditions, it can cause damage to cells or organ functions [69]. Previously, the research findings have shown that numerous natural resources consist of active metabolites with antioxidant properties that are now being exhibited their antioxidant potential by various chemical-based approaches, such as diphenylpicrylhydrazile (DPPH) radical scavenging potential assay and 2,2'-azino-bis (3-ethylbene zothiazoline-6-sulfonic acid) radical scavenging assay (ABTS) [71, 72]. In 2002, Heim et al. (2002) reported that the bio-flavonoids possess healthy antioxidant properties [73].

Kumar et al. [74] tested the antioxidant potential of stem bark of B. racemosa. The stem bark of B. racemosa is developed as crude extracts using methanol solvent to explore its potential in oxidative stress. The formulation is served at various concentrations such as 50, 100, 250, and $500 \mu \mathrm{g} / \mathrm{ml}$. Antioxidant activity levels at different MEBR concentrations have found to be inhibited the lipid peroxidation of the linoleic acid system as $62.43 \%$ at $50 \mu \mathrm{g} / \mathrm{ml}, 67.21 \%$ at $100 \mu \mathrm{g} / \mathrm{ml}, 71.04 \%$ at $250 \mu \mathrm{g} / \mathrm{ml}$, and $76.83 \%$ at $500 \mu \mathrm{g} / \mathrm{ml}$ as well. Especially, the dose of $500 \mu \mathrm{g} / \mathrm{ml}$ has shown significant inhibition in lipid peroxidation system as $76.83 \%$, which is close to that of $\alpha$-tocopherol maintained at $500 \mu \mathrm{g} / \mathrm{ml}$. The inhibition value of the standard drug is $77.93 \%$ at $500 \mu \mathrm{g} / \mathrm{ml}$. They also pointed out that the $B$. racemosa significantly inhibited the linoleic acid peroxidation as $p<0.05$.

In 2007, Dasgupta and De [75] selected eleven medicinal plants and the plants were subjected to explore their antioxidant potential. Among the eleven plants, $B$. racemosa also displayed considerable enzymatic changes in different mechanisms, such as superoxide radical-scavenging activity, DPPH radicalscavenging response, and lipid peroxidation preventive effects.

In 1999, Wang and Wixon [76] reported B. racemosa can possess antioxidant properties due to the presence of phytochemicals such as flavonoids and biflavones. In 2002, Luo et al. [77] reported that the flavonoids and associated polyphenols of vegetables and fruits considerably contributed to be a better antioxidant potential.

Gupta et al. [78] demonstrated the antioxidant potential of $B$. racemosa toward Ehrlich ascites carcinoma (EAC). In their experiment, the lipid peroxidation levels rise to about $48.9 \%$ in EAC, which are substantially reduced by doses of 50,100 , and 200 $\mathrm{mg} / \mathrm{kg}$ of ethanol solvent combined stem bark extracts of $B$. racemosa. The various concentrations of preparation reduced the lipid peroxidation levels to $11.4 \%$ at $50 \mathrm{mg} / \mathrm{kg}, 23.6 \%$ at $100 \mathrm{mg} / \mathrm{kg}$, and $31.4 \%$ at $200 \mathrm{mg} / \mathrm{kg}$. The various concentrations of preparation reduced the lipid peroxidation levels to $11.4 \%$ in $50 \mathrm{mg} /$ $\mathrm{kg}, 23.6 \%$ in $100 \mathrm{mg} / \mathrm{kg}$, and $31.4 \%$ in $200 \mathrm{mg} / \mathrm{kg}$. In their experiment, the glutathione (GSH) levels significantly decreased in mice. The various doses of preparation have substantially raised the GSH level in cancerous mice as $7.4 \%$ at $50 \mathrm{mg} / \mathrm{kg}, 14.2 \%$ at $100 \mathrm{mg} /$ $\mathrm{kg}$, and $22.0 \%$ at $200 \mathrm{mg} / \mathrm{kg}$. Superoxide dismutase (SOD) levels in the liver of cancer mice decreased by about $35.6 \%$. SOD levels are significantly increased following doses of 50, 100, and $200 \mathrm{mg} / \mathrm{kg}$. SOD levels substantially increases as $13.4 \%$ in $50 \mathrm{mg} / \mathrm{kg}, 23.9 \%$ in $100 \mathrm{mg} / \mathrm{kg}$, and $27.2 \%$ in $200 \mathrm{mg} / \mathrm{kg}$.

\section{Anti-helminthic activity}

Parasitic Helminthiasis has been recorded as a serious worm infestation and has been reported to be a major health issue worldwide. Hundreds of millions human infections by helminthes exist worldwide and has increased through world travel and immigration from the developing countries [79]. Hence, the previous research has been focused to find nature-based novel drugs for Helminthiasis. In this regard, Kumar et al. [80] 
studied anthelmintic analysis on Pheretima posthuma, which was tested by using the solvents Petroleum ether, Ethanol, and aqueous mixed whole parts of plants. They are prepared at the concentrations of extract as 50, 75, and $100 \mathrm{mg}$. This research has accomplished with the standard drug Albendazole. Albendazole is used as a comparative agent for evaluating the anti-helmintic potential of plant extracts. After treatment, the paralysis and death of worms are also measured in all the tested concentrations. The tested extracts took time to paralyze the worms, which depend upon the dosage of extracts. The different concentrations of aqueous extracts have paralyzed the worms at $52 \pm 0.2 \mathrm{~min}$ in $50 \mathrm{mg}, 41 \pm 0.6$ min in $50 \mathrm{mg}$, and $36 \pm 0.6 \mathrm{~min}$ in $100 \mathrm{mg}$. Whereas, various concentrations of ethanolic extracts have paralyzed the worms at $36 \pm 0.6 \mathrm{~min}$ in $50 \mathrm{mg}, 31 \pm 0.8 \mathrm{~min}$ in $50 \mathrm{mg}$, and $24 \pm 0.1 \mathrm{~min}$ in $100 \mathrm{mg}$. Furthermore, the various concentrations of petroleum ether extracts have paralyzed the worms at $58 \pm 0.8 \mathrm{~min}$ in $50 \mathrm{mg}, 45 \pm 0.1$ min in $50 \mathrm{mg}$, and $42 \pm 0.2 \mathrm{~min}$ in $100 \mathrm{mg}$. Similarly, the mortality duration of worms are also noted at different concentrations of $B$. racemosa solvents. The tested aqueous extracts showed mortality time of worms as 59 $\pm 0.3 \mathrm{~min}$ in $50 \mathrm{mg}, 50 \pm 0.3 \mathrm{~min}$ in $75 \mathrm{mg}$, and $40 \pm 0.4$ $\mathrm{min}$ in $100 \mathrm{mg}$ as well. Anti-helminthic activity is found on a dose-dependent basis, ethanol preparations showed a significant activity with that of the albendozole drug than aqueous and petroleum ether. Based on the results, the Kumar et al. [80] recommended that the plants extracts should be made through the ethanolic solvents and that active metabolites should be isolated from the plant for analysis.

\section{Anti-filarial activity}

Parasitic Filarial disease is a commonly neglected mosquito borne disease in the tropics. Classified under the endemic diseases, has infected around 120 million people with 1.2 billion at a higher risk according to the reports of WHO [81]. The nematode causing filariasis, Wuchereria bancrofti, is responsible for the $91 \%$ of the infections while the remaining infections (9\%) is produced by Brugia malayi and Brugia timori, especially in the Southeast Asian Countries. They inhabit the lymphatic system and further harm the tissue by producing hydrocele, lymphedema, and elephantiasis. Long-term permanent disability which accounts for the second largest kind of disability is caused by filariasis $[82,83]$.

In 2012, Sashidhara et al. [24] found that the Galactolipids as potential anti-filarial agents against the human lymphatic filarial parasites. The Galactolipids are isolated from the leaves of $B$. racemosa. They are fractionated as two classes of compounds such as galactolipid and catechin, which are isolated in n-butanol fraction. The isolations (2S)-1, 2-di-O-linolenoyl-3-O- $\alpha$ galactopyranosyl-(1/6)-O- $\beta$-galactopyranosyl glycerol, (2S)-1-O-linolenoyl-2-O-palmitoyl-3-O- $\alpha$-galactopyranosyl-(1/6)-O- $\beta$-galactopyranosyl glycerol, and (2S)-1-Ooleoyl-2-O-palmitoyl-3-O- $\alpha$-galactopyranosyl-(1/6)-O- $\beta$ galactopyranosyl glycerolare characterized galactolipids, whereas the isolation (-)-epiafzelechin, (-)-epicatechin, and (-)-catechinare categorized as catechins together with protocatechuic acid.

Prior to $n$-butanol fractionation, the crude ethanolic extract of $B$. racemosa leaves was tested on $B$. malay $i$ by in vitro assay, which showed (F1) $80 \%$ of migration reduction ratio in adult filarial parasites. In this crude extract analysis, the worms did not reveal $100 \%$ reduction in its migration, though it is paralyzed and only a tiny number of parasites have migrated slowly.

\section{Analgesic activity}

A research in 2005 has proved that Methanol mixed with $B$. racemosa stem bark possessed remarkable analgesic efficacy at the dose of $200 \mathrm{mg} / \mathrm{kg}$. In writhing method, the inhibition activity is shown to be $53.41 \%$. In hot plate method, the rate of reaction time significantly increased at the dose of $200 \mathrm{mg} / \mathrm{kg}$, which improved from $9.36 \pm 0.74$ to $16.57 \pm 1.34$. Aspirin and morphine are used as control drugs to determine the ability of stem bark of $B$. racemosa. This is tested on acetic acidinduced writhing and the hot plate method pain-induced mice as well. Aspirin is used as a correspondent to analgesic action in acetic acid-induced writhing mice, whereas in the hot plate process, morphine is used as an analgesic agent in pain-induced mice. This experiment also examined analgesic efficacy using a mixture of MEBR and authorized drugs. There, the combinations exposed more potent analgesic activities than the individual doses of approved drugs and prepared extracts. Especially, the combinations of aspirin and MEBR exhibited remarkable writhes inhibition percentages such as $71.36 \%$ in $100+50 \mathrm{mg} / \mathrm{kg}, 77.04 \%$ in $100+100 \mathrm{mg} / \mathrm{kg}$, and $84.02 \%$ in $100+200 \mathrm{mg} / \mathrm{kg}$.

To determine the analgesic activity, the stem bark of $B$. racemosa was subjected to an analgesic experiment on tail lesion-induced albino Wister rats [84]. Analgin is used as a testing drug to compare the effectiveness of the $B$. racemosa stem bark with that of a commercial drug. The extracts are prepared using aqueous and ethanolic solvents and tested at different doses with each solvent at $100 \mathrm{mg} / \mathrm{kg}$ and $200 \mathrm{mg} / \mathrm{kg}$ respectively. Borikar et al. [84] reported that B. racemosa stem bark displayed substantial analgesic efficacy in Wister rat tail lesions when added with alcohol. They also reported that rats treated with aqueous extracts at a dose of $100 \mathrm{mg}$ had no analgesic activity in tails. Eventually, $200 \mathrm{mg}$ of B. racemosa alcoholic extract has a stronger analgesic 
function similar to10 $\mathrm{mg}$ of analgin. In their experiment, the aqueous extract did not possess analgesic action due to a lack of adequate dose.

Chandrasekar and Prasanna [85] tested the analgesic potency of $B$. racemosa stem bark when mixed with petroleum ether. In order to evaluate the activity, the researchers used the animals in two techniques, such as acetic acid-induced writhing and thermal stimulusinduced pain method (hot plate methods). The animals were classified into three groups in both acetic acid induced writhing and hot plate method. In their trial, Aspirin was used as a control agent to the writhing paininduced rats by acetic acid, whereas Pentazocin was used as a control agent to the pain-induced rats by hot plate method. Eventually, Chandrashekar and Prasanna [85] reported that the petroleum ether mixed stem bark of $B$. racemosa had no substantial analgesic effects in animal model. From the conclusion of previous studies, we realized that it exposes efficient activities when the extract combined with the high polar solvents such methanol and alcoholic solvents.

\section{Hepatoprotective activities}

A research in 2004 has shown that the methanol solvent mixed stem bark of $B$. racemosa has potent hepatoprotective potentials against tetrachloride and paracetamol-induced liver damage in rats. The mixture of methane solvent and stem bark is administered to rats at concentrations of 50,100, and $200 \mathrm{mg} / \mathrm{kg}$. They used various enzymatic activities, such as GSH, SOD, and catalase function, in rats following induction in liver injury. Following doses of MEBR, the enzyme activity was analyzed to assess the effectiveness of $B$. racemosa drugs. In paracetamol administered rats, the GSH levels decreased substantially compared to the normal group, while the overall homogenate of rats improved at doses of $50 \mathrm{mg}$ as $2.43 \mu \mathrm{mol} / \mathrm{g}, 100 \mathrm{mg}$ as $3.71 \mu \mathrm{mol} / \mathrm{g}$, and $200 \mathrm{mg}$ as $4.42 \mu \mathrm{mol} / \mathrm{g}$. When seen in percentages, the different concentrations of MEBR effectively increased as $22.9 \%$ in $50 \mathrm{mg}, 57.2 \%$ in $100 \mathrm{mg}$, and $76.2 \%$ in 200 $\mathrm{mg}$, when compared to the paracetamol group. Similarly, GSH levels in the normal group were assessed as higher than those in the carbon tetrachloride $\left(\mathrm{CCl}_{4}\right)$ administered group. There, the GSH levels were higher than that of the administered $\mathrm{CCl}_{4}$. Different doses of MEBR increased the GSH levels as $33.7 \%$ in $50 \mathrm{mg}, 63.8 \%$ in 100 $\mathrm{mg}$, and $97.2 \%$ in $200 \mathrm{mg}$.

The SOD levels were also decreased as $53.83 \mathrm{U} / \mathrm{mg}$ in paracetamol administered group when compared to normal group $(91.76 \mathrm{U} / \mathrm{mg})$. The SOD levels were also decreased as $53.83 \mathrm{U} / \mathrm{mg}$ in paracetamol administered group when compared to normal group $(91.76 \mathrm{U} / \mathrm{mg})$. Following treatment at doses of 50,100 , and $200 \mathrm{mg} / \mathrm{kg}$ of MEBR, the SOD levels improved dramatically as
$17.6 \%$ in $50 \mathrm{mg} / \mathrm{kg}, 40.0 \%$ in $100 \mathrm{mg} / \mathrm{kg}$, and $88.1 \%$ in $200 \mathrm{mg} / \mathrm{kg}$. Similarly, the activity is decreased as 57.23 $\mathrm{U} / \mathrm{mg}$ in $\mathrm{CCl}_{4}$ administered group when compare to the normal group $(91.76 \mathrm{U} / \mathrm{mg})$. Following treatment at doses of 50, 100, and $200 \mathrm{mg} / \mathrm{kg}$ of MEBR, the SOD levels improved dramatically as $20.9 \%$ in $50 \mathrm{mg} / \mathrm{kg}$, $37.7 \%$ in $100 \mathrm{mg} / \mathrm{kg}$, and $87.7 \%$ in $200 \mathrm{mg} / \mathrm{kg}$. The different concentrations of MEBR revealed efficient catalase enzyme activities in both paracetamol and tetrachloride induced hepatic damage. In paracetamolinduced hepatic damage, the different concentrations of MEBR increased the catalase enzyme activity as $25.9 \%$ in $50 \mathrm{mg}, 54.8 \%$ in $100 \mathrm{mg}$, and $75.2 \mathrm{in} 200 \mathrm{mg}$ respectively, whereas in paracetamol-induced hepatic damage, the different concentrations of MEBR increased the catalase enzyme activity as $25.9 \%$ in $50 \mathrm{mg}, 61.4 \%$ in 100 $\mathrm{mg}$, and $82.9 \%$ in $200 \mathrm{mg}$ respectively. Based on the experimental outcome, Gupta et al. [78] reported that the stem bark of Bauhinia racemosa had active hepatoprotective metabolites. They also indicated that the metabolites of MEBR could be used as alternate drugs to repair the liver cells from the hepatic injury of paracetamol and tetrachloride.

Subrayaet al [86]. conducted an experiment on albino Wister rats to restore tetrachloride-induced hepatic damage to the liver cells, which was studied using ethyl acetate solvent blended with the stem bark extracts of Bauhinia racemosa. They induced hepatic injury in the rats group of II-V by using $\mathrm{CCl}_{4}$. Then, the approved drug silymarin with a dose of $100 \mathrm{mg}$ was administered the rats group-III, whereas the dose $200 \mathrm{mg}$ ethyl acetate combined stem bark extracts of $B$. racemosa was administered to the group IV. Based on their research findings, they stated that when compared to the approved drug silymarin, the mixtures of stem bark of B. racemosa revealed remarkable hepatoprotective potential. In 1979, Harborn [87] stated that the previous researchers reported the ethanol solvent mixed plant extracts were found to have much more amount flavonoids and glycosides. In phytochemical analysis of Subraya et al. [86], the ethyl acetate mixed stem bark of $B$. racemosa revealed the presence of flavonoids by qualitative analysis such as ferric chloride, alkaline reagent, and shinoda test.

In 2005, Kumaret al [74]. analyzed the hepatorenal and hematology potentiality of $B$. racemosa with various concentrations such as $100 \mathrm{mg} / \mathrm{kg}, 200 \mathrm{mg} / \mathrm{kg}$, and 400 $\mathrm{mg} / \mathrm{kg}$. The stem bark extracts of $B$. racemosa was mixed with methanolic solvent and administered to the renal failure induced rats for analyze its potentials. In biochemical parameters, the mixtures of $B$. racemosa did not reveal any significant changes at doses of $100 \mathrm{mg} / \mathrm{kg}$ and $200 \mathrm{mg} / \mathrm{kg}$. However, the bilirubin and serum enzymes such as glutamic pyruvic transaminase (GPT), 
glutamic oxaloacetic transaminase (GOT), and alkaline phosphatase (ALP) were enhanced at a dosage of 400 $\mathrm{mg} / \mathrm{kg}$. Furthermore, the levels of urea, uric acid, creatinine, cholesterol, and glucose were altered slightly in the rats treated at the dose of $400 \mathrm{mg} / \mathrm{kg}$. Similarly, no substantial differences in hematological parameters such as white blood cells, neutrophils, lymphocytes, monocytes, red blood cells, hemoglobin, hematocrit (Hct), mean corpuscular volume (MCV), mean corpuscular hemoglobin $(\mathrm{MCH})$, mean corpuscular hemoglobin concentration (MCHC), and platelets were revealed in rats treated at the doses of $100 \mathrm{mg} / \mathrm{kg}$ and $200 \mathrm{mg} / \mathrm{kg}$. These parameters were altered in rats treated at the dose of $400 \mathrm{mg} / \mathrm{kg}$. The renal failureinduced rats were subjected to experiments for hepatorenal potential of $B$. racemosa. In the rats treated at the doses of 100 and $200 \mathrm{mg}$, there were no substantial changes revealed in its liver, while the fatty liver was found in the rats treated at a dosage of $400 \mathrm{mg} / \mathrm{kg}$.

\section{Anti-ulcerative effects}

At present, treatment of peptic ulcer is not satisfactory to humans due to the use of synthetic drugs, because all of the medicines used trigger several adverse reactions, such as arrhythmias, impotency, gynecomastia, and hematopoietic changes. We can escape from the adverse effects of synthetic drugs by using medicinal plants. In 1995, the flower buds of B. racemosa were prepared with methanol solvent and administered to ulcer-induced rats at a dosage of $2 \mathrm{~g} / \mathrm{kg}$ [88]. Akhtar and Ahmed [88] have also reported that the flower buds of B. racemosa had a substantial decrease in acid production, pepsin production, and volume of gastric acid of ulcer-induced rat peptic activities. It may happen due to a decline of glandular secretion. In their study, the methanolic extracts of B. racemosa substantially improved the concentration of fucose and sialic acid in carbohydrate without a proteins reduction, and the mucin activity has also not changed. In ulcer-induced rats, methanol mixtures of $B$. racemosa flower buds inhibited ulcer formation at almost $64 \%$. They reported that treatment not only inhibited acids and pepsin but also reinforced the mucosal barrier in ulcer rats. The ulcer genes and drug targets of the human gastric acid pathway are shown in Fig. 2.

\section{Anti-cancer activities of the herb}

All around the world, cancer is a leading cause of mortality. According to the reports of World Health Organization (WHO), the incidence of cancer cases is expected to rise by $75 \%$ in 2030 due to the population growth and the change in life style. Several chemotherapeutic drugs with different biochemical/ molecular targets have been extensively used in this world to cure various types of cancers. At the same time, the drugs should not cause any adverse effects on humans. Researchers have been struggling to find effective therapeutic approaches to cancer and novel anti-cancer drugs over the last few decades. Hence, the search for alternative drugs from natural sources is important and it should also be less toxic [69]. Over the last few decades, a number of studies have revealed that B. racemosa extracts have anticancer properties such as antitumor effects in Ehrlich ascites carcinoma hepatocarcinogenesis and cervical cancer. In 2004, Gupta et al. [78] tested the capacity of B. racemosa stem bark in cancer mice (carcinoma-induced mice). Before being given to the mice, the stem bark extracts of $B$. racemosa were mixed with methanol solvents. Then, it was administered to the mice for examination of these kinds of biochemical parameters such as toxicity, antitumor resistance, lipid peroxidation, and antioxidant property. The normal body weights of tested mice were $20.70 \pm$ 0.12 g. After administered the EAC, the body weights gradually increased to $26.70 \pm 0.16$ from the usual weight, whereas after given the stem bark of $B$. racemosa formulation in cancer mice, the body weights of the mice gradually reduced to $24.60 \pm 0.19$ in $50 \mathrm{mg}, 22.50$ $\pm 0.13 \mathrm{in} 100 \mathrm{mg}$, and $21.20 \pm 0.14$. Also, $20 \mathrm{mg}$ dose of 5 -floururacil has reduced the body weight to $20.70 \pm$ 0.09 in cancer mice. Then, $200 \mathrm{mg}$ of MEBR reduced the body weight similar to that of 5 -fluorouracil. They measured the life span of cancer mice after the treatment of MEBR, raising the life span to 34.12 in $50 \mathrm{mg}$, $68.75 \mathrm{in} 100 \mathrm{mg}$, and $99.50 \mathrm{in} 200 \mathrm{mg}$. The lifespan of $20 \mathrm{mg}$ of prescribed drugs improved as 119.49 , whereas they also revealed no life span for untreated EAC mice. The different concentrations of MEBR have reduced the volume of tumor cells in EAC mice as $3.37 \pm 0.07$ in 50 $\mathrm{mg}, 2.41 \pm 0.03$ in $100 \mathrm{mg}$, and $1.20 \pm 0.01$ in $200 \mathrm{mg}$. This value was compared with untreated EAC-bearing mice that possessed the volume of tumor cells as $4.51 \pm$ 0.07 . The viability of tumor cells considerably declined to $3.37 \pm 0.07$ in $50 \mathrm{mg}, 2.41 \pm 0.03$ in $100 \mathrm{mg}$, and 1.20 \pm 0.01 in $200 \mathrm{mg}$. Gupta et al. [78] reported that MEBRtreated animals at doses of 50,100 , and $200 \mathrm{mg} / \mathrm{kg}$ decreased body weight, tumor volume, packed cell volume, tumor cell count, and also reduced hematological parameters close to that of healthy mice. Their short-term toxicity studies reported that there were no adverse effects.

Azizur Rahman et al. [25] tested the apoptotic potential of Bauhinia racemosa stem bark against HeLa cell lines. Before being given to the mice, the stem bark extracts of $B$. racemosa were mixed with methanolic solvents. They treated HeLa cells with various concentrations of MEBR such as $25 \mu \mathrm{g} / \mathrm{ml}, 50 \mu \mathrm{g} / \mathrm{ml}$, $100 \mu \mathrm{g} / \mathrm{ml}$, and $200 \mu \mathrm{g} / \mathrm{ml}$. HeLa cell viability significantly reduced in the treatment of MEBR 


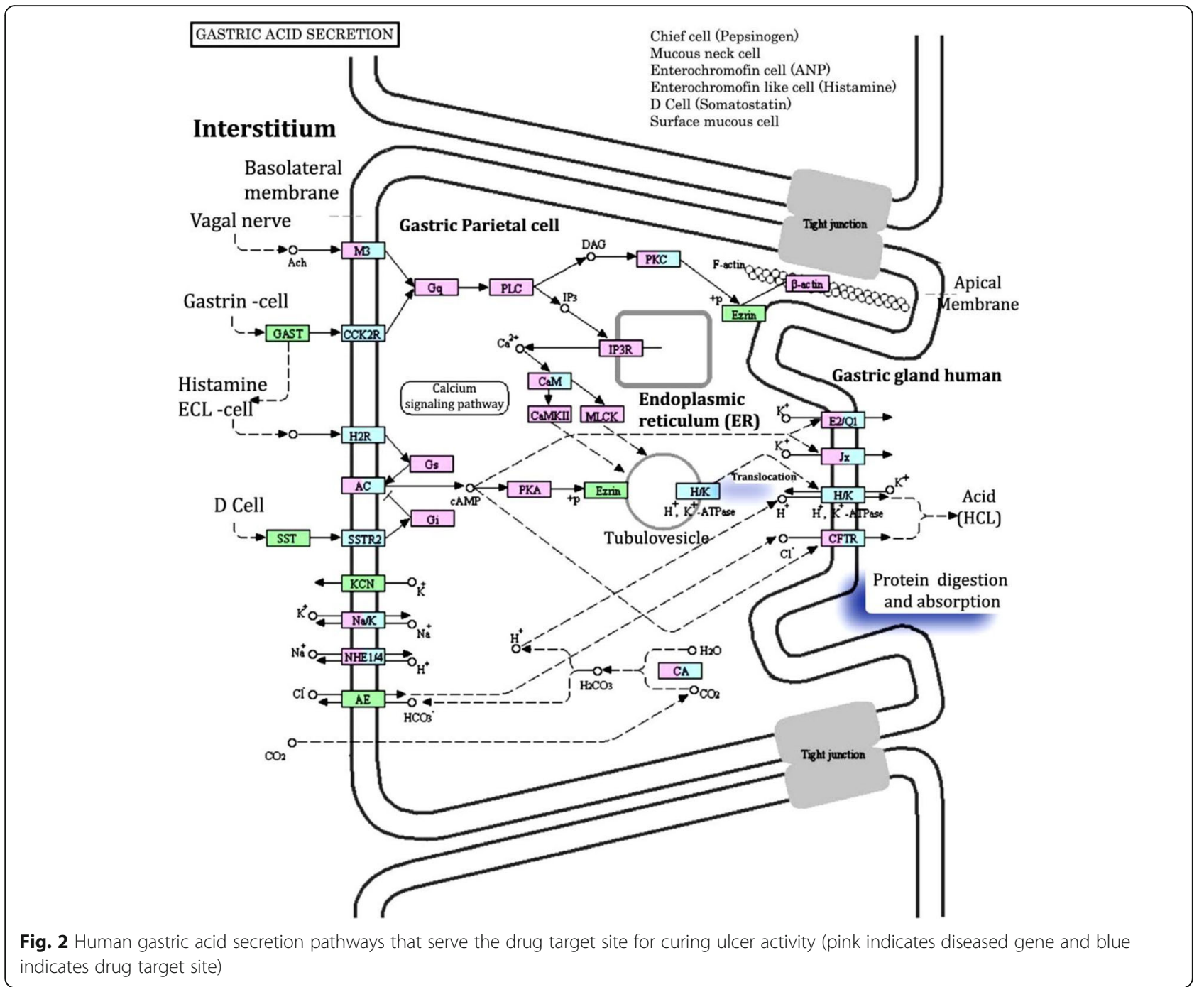

concentrations $\left(p<0.001, \mathrm{IC}_{50}=80 \mu \mathrm{g} / \mathrm{ml}\right)$, which decreases the cell viability of HeLa similar to that of tamoxifen $\left(p<0.001, \quad \mathrm{IC}_{50}=48 \mu \mathrm{g} / \mathrm{ml}\right)$ in a concentration-dependent manner. At the concentrations of $25 \mu \mathrm{g} / \mathrm{ml}$ and $50 \mathrm{mg} / \mathrm{ml}$, the cell viability decreased to $90.90 \%$ and $78.20 \%$ respectively as compared to control; while at doses of $100 \mu \mathrm{g} / \mathrm{ml}, 300$ $\mu \mathrm{g} / \mathrm{ml}$, and $500 \mu \mathrm{g} / \mathrm{ml}$, the cell viability decreased to $43.43 \%, 22.42 \%$, and $8.25 \%$ respectively. Azizur Rahman et al. [25] reported that the concentrations 100 $\mu \mathrm{g} / \mathrm{ml}$ and $300 \mu \mathrm{g} / \mathrm{ml}$ of MEBR have notable cytotoxic effects against the HeLa cancer cell line and their study was subjected to further tests. Results of the study demonstrated that total phenolic content in MEBR was $886.8252 \mathrm{mg}$ GAE/g dried extract. Their findings revealed that the overall phenolic content was $886.8252 \mathrm{mg}$ GAE/g of dried extract in MEBR. Eventually, they reported that it could be a new possible cytotoxic agent to HeLa cancer cells.

\section{Anti-histaminic activities of the medicinal plant}

The antihistamine potential of $B$. racemosa leaves was analyzed on Clonidine-induced catalepsy mice [89]. This was tested by using the ethanol combined leaves extract of $B$. racemosa. Then, the ethanolic extracts of Bauhinia racemosa (EEBR) was administered to catalepsy induced mice at dose of $50 \mathrm{mg} / \mathrm{kg}$, whereas the Pheniramine maleate was used as the standard drug for catalepsyinduced mice. Catalepsy was inhibited by the EEBR at a dosage of $50 \mathrm{mg}$, while it was inactive against haloperidol-induced catalepsy. Finally, Nirmal et al. [89] reported that the ethanol extract of leaves of $B$. racemosa will be an effective alternative medicine for asthma.

\section{Anti-pyretic activities}

An antipyretic potential of $B$. racemosa stem bark was analyzed by yeast-induced pyrexia rats with MEBR at doses of 50,100, and $200 \mathrm{mg} / \mathrm{kg}$ [70]. The antipyretic 
test started in the first hour on rats and the rats were monitored for $4 \mathrm{~h}$ after the administration of extracts. Compared to paracetamol (150 mg/kg), the oral administrations of MEBR at various concentrations have showed significant antipyretic potential in the yeastinduced rectal temperature.

A research in 2009 tested the antipyretic potential of stem bark of B. racemosa on pyrexia-induced male albino rats [90]. Before being given to the mice, the stem bark extracts of $B$. racemosa were mixed with alcohol and aqueous solvents. Then, the preparations were treated to the pyrexia induced rat at doses of $100 \mathrm{mg}$ and $200 \mathrm{mg}$ in each solvent to two independent groups. In rats with pyrexia, the $200 \mathrm{mg}$ of aqueous extracts and 100 and $200 \mathrm{mg}$ of alcoholic extracts possessed significant potential that were considerably reduced when the temperatures were maintained at 5\% in rats within $3 \mathrm{~h}$. Borikar et al. [90] reported that $200 \mathrm{mg}$ of alcohol extracts reduced the rat's temperature to $99.5 \pm 0.225$ from $101.91 \pm 0.267$, which has also reduced the rat's temperature as close to that of paracetamol (99.56 \pm 0.212 ) treatment.

\section{Anti-diabetic effects}

Diabetes mellitus is characterized by glucose hyperglycemia, hypoglycemia, hyperlipidemia, hyperlipidemia, and lipid and protein metabolisms defects. Obesity and lack of physical activity play an important role in diabetes. About 3.5 million deaths occur worldwide annually due to complications such as retinopathy, diabetic coma, nephropathy, neuropathy, diabetic ketoacidosis, and so on. There is an increase in illness-related mortality and morbidity, despite developments in the diagnosis and prevention of disease. Researchers are therefore keen to examine drugs from natural sources, especially plant metabolites. A research in 2012 tested the anti-diabetic potentials of B. racemosa leaves on alloxan-induced diabetic rats. Before being given to the rats, the leaf extracts of $B$. racemosa were mixed with methanol and aqueous solvents [91]. Then, the preparations were treated to the hyperglycemiainduced rats at doses of $200 \mathrm{mg}$ and $400 \mathrm{mg}$ in each solvent. In hyperglycemic rats, 200 and $400 \mathrm{mg}$ of aqueous extracts of Bauhinia racemosa (AEBR) and MEBR have significantly increased body weight and also decreased body blood sugar levels when compared to the Pioglitazone. Prusty et al. [91] stated that extracts of AEBR and MEBR have increased pancreatic exocrine functions, such as insulin secretion, fatty liver changes, recovering the dead cells of $\beta$-islets, and also increased transport of blood glucose to the periphery.

Furthermore, in 2017, Kumar et al. [92] used $B$. racemosa leaves at doses of $250 \mathrm{mg}$ and $500 \mathrm{mg}$ to test their anti-diabetic efficacy in hyperglycemic animals.
The anti-diabetic pathogenic activity on the 3T3-L1 cell line was also evaluated. A $500 \mathrm{mg}$ dosage substantially reduced the blood glucose level $(58.8 \mathrm{mg} / \mathrm{dl})$ in a fasted rat within $4 \mathrm{~h}$, which was equal to that of diabetic drug glibenclamide $(51.4 \mathrm{mg} / \mathrm{dl})$ in the in-vitro study. Oral glucose levels were also measured in three stages, such as $0 \mathrm{~min}, 30 \mathrm{~min}$, and $90 \mathrm{~min}$, for glucose primed rats. At $90 \mathrm{~min}$, the glucose level was slightly lowered as $115.65 \mathrm{mg} / \mathrm{dl}$ from $152.92 \mathrm{mg} / \mathrm{dl}$ by $500 \mathrm{mg}$, which was closer $(90.44 \mathrm{mg} / \mathrm{dl})$ to that of the diabetic medication glibenclamide. At the conclusion of the trial, fasting serum glucose levels in diabetic rats decreased as much as $134.70 \mathrm{mg} / \mathrm{dl}$ in $250 \mathrm{mg}$ and $143.88 \mathrm{mg} / \mathrm{dl}$ in $500 \mathrm{mg}$, while FSG levels also changed at weekly intervals as per dose-dependent treatment. Figure 3 shows the drug target site and the enzymes involved in type II diabetes mellitus of humans.

\section{Larvicidal activity of the medicinal plant}

Malik et al. [93] studied the larvicidal potential of $B$. racemosa and Lantana camera against the larvae of Anopheles stephensi mosquito, which were analyzed by using the solvents chloroform and ethyl acetate. Among the plant extracts, the ethyl acetate extracts of $B$. racemosa exposed efficient larvicidal effects. Based on their research outcomes, they reported that the plants can be used as an alternative way to control insects and also used to reduce the adverse effects of chemical pesticides in the environment.

\section{Anti-HIV-1 activity of the B. racemosa}

Human immunodeficiency virus (HIV) continues to be a serious public health issue worldwide. According to Palshetkar et al. [94], there are 37.9 million individuals are living with HIV worldwide, 36.2 million of them are adults and 1.7 million of them are below the ages of 15 years. Further, 1.7 million people are newly infected with viral infections. Globally, 770,000 people have globally died from acquired immunodeficiency syndrome (AIDS)-related diseases. Consequently, an effective drug is required to control the mortality and morbidity of HIV from natural sources. If it could be a plant, it will be better [94].

Khaled et al. [95] tested the anti-HIV activities of the stem of $B$. racemosa and its fractions by using the solvents methanol, ethyl acetate, $n$-butanol, and aqueous. Methanolic extracts of $B$. racemosa demonstrated greater anti-HIV efficiency, while other fractions displayed less anti-HIV capacity. Phytochemicals have also been studied in methanol and other solvents extracts of B. racemosa. Eventually, flavonoids, tannins, and terpenes have been found. Furthermore, the methanol extracts were subjected to further studies on isolation of phytochemicals. In this isolation study, the 


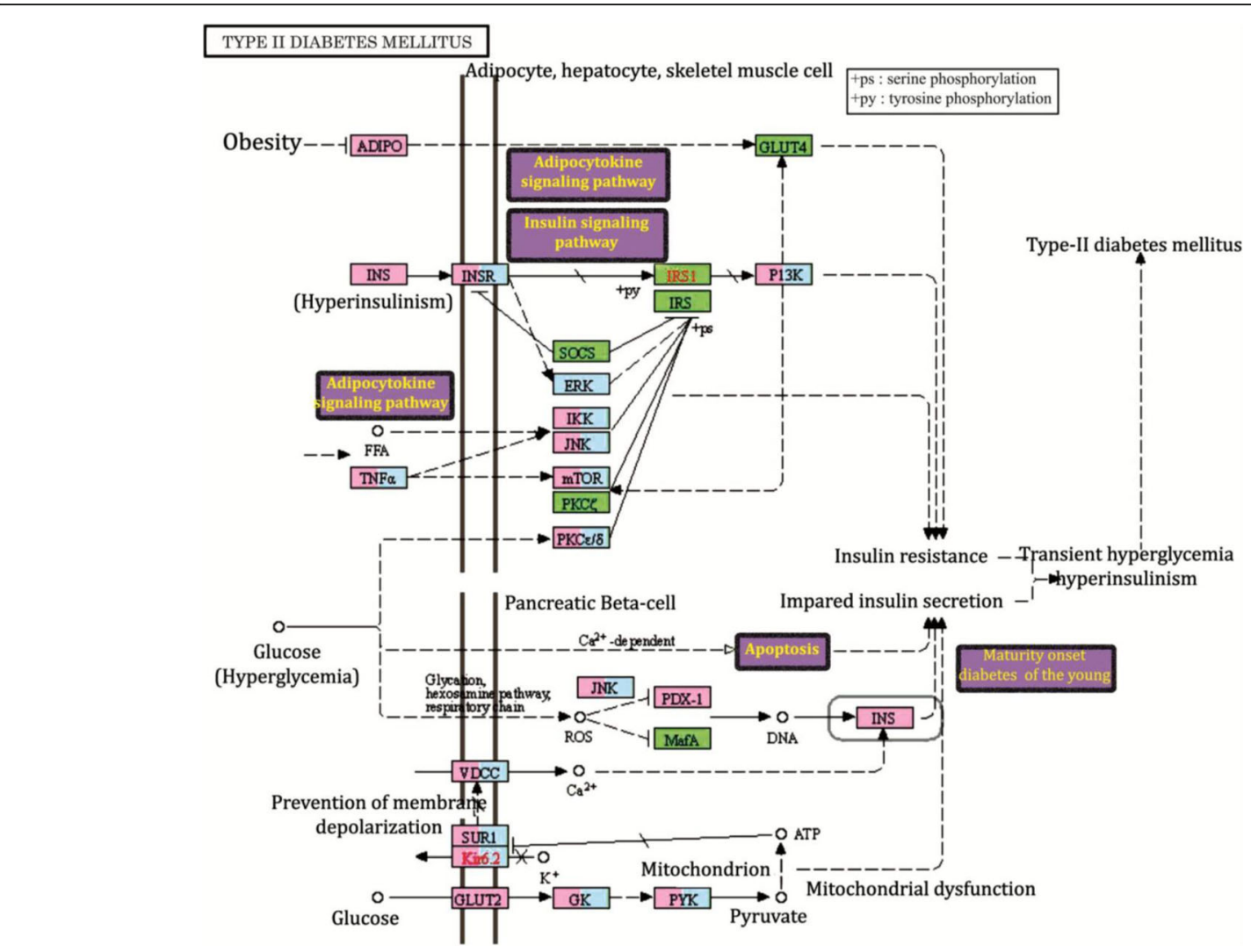

Fig. 3 Human type-II diabetes mellitus pathways that serve the drug target site for controlling diabetic complications (pink indicates diseased gene and blue indicates drug target site)

phytochemicals such as triterpenic acids (oleanoic and ursolic), two hydrolysable tannins (gallic and ellagic acids) and three flavonoids (luteolin, quercetin 3-O- $\beta$ glucoside, and myricetin 3-O- $\beta$-glucoside) are identified. Khaled et al. [95] reported that methanol extract of $B$. racemosa has potential as an anti-HIV-1 agent. This is assumed that owing to the presence of different phytochemicals in the extracts of methanol, the antiviral activity can be revealed.

\section{Toxicity assessment}

In order to know the toxicity of $B$. racemosa leaves, at a dose of up to $2000 \mathrm{mg} / \mathrm{kg}$ were subjected to acute toxicity analyses prior to the diabetic clinical trial. Kumar et al. [92] report that the treatment did not cause any adverse effects and fatalities when administered to rats.

\section{Conclusions}

Plant metabolites have been sold in the market at high prices to satisfy the human health requirements. But we can procure these metabolites from native plants in rural and urban areas. Traditional applications, phytochemical, and pharmacological profiles of $B$. racemosa have been pointed out in detail in this review through the literature available since 1935. This review clearly reflects the importance of $B$. racemosa in the ayurvedic medicinal system, especially in the case of cancer. This plant extracts are preferred for treatment of cancer, especially during the early stages in Ayurveda. In southern India, this species is being nurtured in residential areas by traditional people to avoid the thundering impact because they believe that it is capable of neutralizing thunder. Thus, the plant is referred to as the lightning arrester (Idithangi) by the Tamilians.

As set out in Table 1, it has a wide range of traditional uses and is being treated by tribals and other traditional people worldwide. However, the plant has not yet been widely researched in the aspects of phytochemistry and pharmacology. To date, almost 37 phytoconstituents have been identified and extracted from different parts of the plant. B. racemosa has a larger quantity of flavonoids. Generally, flavonoid compounds have been more abundantly reported as having wide therapeutic potentials such as neuroprotective, anti-cancers, antihyperglycemia, anti-ulcer, steroid-genesis modulators, anti-inflammation, and so on [96]. These flavonoids (phytoconstituents) have been used for decades to minimize the health problems of the human race. Those 
therapeutic potentials are expressed due to the existence of these secondary metabolites (Table 2). This plant formulation is also being marketed under the name Masanumas 2 as a tablet to prevent abortion during the second month of pregnancy. To extract the unidentified and/or unknown molecule, phytochemical research is extensively needed yet.

Despite the existence of biologically active molecules such as Mome inositol, Neophytadiene, Resveratrol, Lupeol, Octacosane, $\beta$-sitosterol, $\beta$-amyrin, Racemosol, Galactolipid, Catechin, Betulin, Quercetin, Rutin, and Kaempferol, only a limited number of pharmacological studies have been described on this plant. Further pharmacological studies are extensively needed in this extract as set out in Table 4. We hope that crude extracts will have significant effects on diseases due to the existence of such molecules. Traditionally, B. racemosa has been used for the treatment of dysentery, diarrhea, malaria, influenza, epilepsy, vomiting, edema, constipation, gastric, dyspepsia, and convalescents. Even though, no research has been conducted to date on the traditional uses of this herb. The extracts should therefore be subjected to pharmacological trials (in vitro and in vivo) to determine their biological ability. Toxicity studies in pharmacology and traditional uses are required to clarify their exact enzymatic pathways leading to toxic effects.

According to the pharmacological studies, we realized that the methanol and ethanol extracts of B. racemosa have shown high pharmacological activities. Consequently, in most pharmacology experiments, ethanol and methanol extraction were used. To date, no single drug (one product) of $B$. racemosa has been developed globally. In Ayurvedic medicine, it is used as a decoction at the early stage of cancer cases. This plant bark is also mixed with other plants parts and is recommended for the prevention of miscarriage during the second month of pregnancy.

Furthermore, a number of pharmacological studies have confirmed the potential antioxidant activity of B. racemosa. The antioxidant potential can be exposed by the presence of flavonoids at higher concentrations. Therefore, as an anti-oxidant agent, $B$. racemosa still has a broad testing part for researchers to analyze based on the existing research source, and it is important to further analyze its therapeutic effectiveness. However, there are several more pharmacological studies in which B. racemosa have positive effects on cancer, pathogens, hyperlipidemia, antioxidants, and other diseases. In addition, existing pharmacological experiments and clinical data have not revealed any harmful effects of $B$. racemosa so far. As far as the phytochemicals are concerned, pharmacological and toxicological aspects are to be explored via thorough research on this plant.

This review also suggests that more pharmacological experiments are needed in this plant for knowing its therapeutic potential against certain mortal diseases. This review could help future researchers to understand the existing pharmacological capabilities of B. racemosa. We also hope that this review will support the phase of drug development in the pharmaceutical sector.

\begin{abstract}
Abbreviations
B. racemosa: Bauhinia racemosa; APG: Angiosperm phylogeny group; $\beta$ sitosterol: Beta-sitosterol; $\beta$-amyrin: Beta-amyrin; HIV: Human immunodeficiency virus; MeOH: Methyl alcohol; NF-KB: Nuclear factor kappa light chain enhancer; iNOS: Inducible nitric oxide synthase; COX-

2: Cyclooxygenase-2; TNF-a: Tumor necrosis factor alpha; IL-6: Interleukin-6; MEBR: Methanolic extract of Bauhinia racemosa; ROS: Reactive oxygen species; DPPH: Di-phenyl-picryl-hydrazile; ABTS: 2,2'-Azino-bis(3-

ethylbenzothiazoline-6-sulfonic acid; $\mu \mathrm{g} / \mathrm{ml}$ : Microgram/milliliter; EAC: Ehrlich ascites carcinoma; SOD: Superoxide dismutase; LF: Lymphatic filariasis; GSH: Glutathione; $\mathrm{CCl}_{4}$ : Carbon tetrachloride; GPT: Glutamic pyruvic transaminase; GOT: Glutamic oxaloacetic transaminase; ALP: Alkaline phosphatase; HCT: Hematocrit; MCV: Mean corpuscular volume; MCH: Mean corpuscular hemoglobin; MCHC: Mean corpuscular hemoglobin concentration; EEBR: Ethanolic extracts of Bauhinia racemosa; AEBR: Aqueous extracts of Bauhinia racemosa; AIDS: Acquired immunodeficiency syndrome
\end{abstract}

\section{Acknowledgements}

Each author expresses his gratitude to their institutions for providing the opportunity to do develop this manuscript. The first author expresses his thanks to the management of Annai Vailankanni Arts and Science College, Thanjavur for giving the time to do this review.

\section{Authors' contributions}

SP and SV assisted in drawing the outline for the review and collected papers on the plant in a number of ways. In the writing, editing, and revising of the manuscript, RR and KK took part. PKP took part in language revision and polishing of the manuscript. GT and JS had the role to correct the field of taxonomy and pharmacology. NP played a key role in the developing structures of phyto-compounds and helped to correct the phytochemistry part as well. All authors have read and approved the manuscript.

Funding

There is no fund support for doing this review.

Availability of data and materials

All the collected articles and their data's are enclosed in this article in the reference section.

\section{Declarations}

Ethics approval and consent to participate

Not applicable.

Consent for publication

Not applicable.

Competing interests

No conflict of interest between authors.

\section{Author details}

${ }^{1}$ Department of Botany, Annai Vailankanni Arts and Science College (Affiliated to Bharathidasan University, Trichy-24), Bishop Sundaram Campus, Pudukkottai Road, Thanjavur 613007, Tamil Nadu, India. ${ }^{2}$ PG and Research Department of Botany, A.V.V.M Sri Pushpam College (Autonomous), (Affiliated to Bharathidasan University, Trichy-24), Poondi, Tamil Nadu 613 503 Thanjavur, India. ${ }^{3}$ Department of Biology, The Gandhigram Rural Institute (Deemed to be University), Gandhigram, Dindigul, Tamil Nadu, India.

${ }^{4}$ Department of Nanotechnology, Noorul Islam Centre for Higher Education, 
Kumaracoil, Kanyakumari District, Tamil Nadu 629 180, India. ${ }^{5}$ Department of Botany, Government Arts College (Autonomous), (Affiliated to Bharathidasan University, Trichy-24), Kumbakonam 612 002, Tamil Nadu, India. ${ }^{6}$ Department of Chemistry, Annai Vailankanni Arts and Science College (Affiliated to Bharathidasan University, Trichy-24), Bishop Sundaram Campus, Pudukkottai Road, Thanjavur 613007, Tamil Nadu, India.

\section{Received: 2 March 2021 Accepted: 26 April 2021}

\section{Published online: 12 May 2021}

\section{References}

1. Panda P, Das D, Dash P, Ghosh G (2015) Therapeutic potential of Bauhinia Racemosa-a mini review. Int J Pharm Sci Rev Res 32(2):169-179

2. Kirtikar KR, Basu BD (1975) Indian medicinal plants, vol. 2. Bishen Mahendra Pal Singh, Dehradun, p 842-844

3. Wealth of India (1953) Council of Scientific and Industrial Research, Publication and Information Directorate, New Delhi, pp 54-55

4. Sharanabasappa GK, Santosh MK, Shaila D, Seetharam YN, Sanjeevarao I (2007) Phytochemical studies on Bauhinia racemosa Lam, Bauhinia purpurea Linn and Hardwickia binata Roxb. E-J Chem 4(1):21-31. https://doi.org/10.11 55/2007/874721

5. APG IV (2016) An update of the angiosperm phylogeny group classification for the orders and families of flowering plants: APG IV. Bot J Linn Soc 181(1):1-20. https://doi.org/10.1111/boj.12385

6. Kirtiker KR, Basu AD (1935) Indian medicinal plants. Oriental Enterprises, Dehradun

7. Chopra RN, Nayar SL, Chopra IC (1956) Glossary of Indian medicinal plants. Council of Scientific and Industrial Research, New Delhi

8. Joshi P (1982) An ethnobotanical study of Bhils. J Econ Tax Bot 3:257-266

9. Rao TR, Henry AN (1996) The ethnobotany of Eastern Ghats in Andhra Pradesh, India. Botanical Survey of India

10. Pal DC, Jain SK (1998) Tribal medicine, vol 317. Naya Prakash, Calcutta

11. Karuppusamy S (2007) Medicinal plants used by Paliyan tribes of sirumalai hills of Southern India. Nat Prod Radi 6(5):436-442

12. Kar T, Mandal KK, Reddy ES, Biswas AK (2013) Ethnomedicine plants used to cure Diarrhea, Dysentery and Cholera by some tribes of Mayurbhanj district Odissa, India. Life Sci Life lights 2:18-23

13. Ramakrishna N, Reddy S, Sreelakshmi T, Sunitha EM, Saidulu CH, Rajani A (2015) Ethnobotanical survey in common plants of medicinal usage in tribal communities of Naikpods and Parthan of different mandals of Adilabad district, Telungana State, India. Int J Innov Pharm Sci Res 3(10):1500-1512

14. Ayyappan P, Ganesan K, Jayakumararaj R (2016) Ethnobotanic informations on uncommon anti-diabetic medicinal plants from Alagarkoil Forest reserve: evidence based strategic rationale in management of diabetics. Int J Pharma Pharmaceu Res 16(4):515-526

15. Jaganathan GK, Thanh Hoa TH, Liu BL (2016) Ethnobotanical survey of Irular tribes in Pillur valley, Coimbatore, Tamil Nadu (India). Int J Herb Med 4(1):111

16. Valli M, Kumar O, Padal S (2016) Ethnomedicinal plants used for dysentery and diarrhea by tribes in Prakasam District, Andhra Pradesh, India. BMR Phytomed 2(1):1-4

17. Jain M, Shrivastava PN, Samar R (2018) Survey of ethnobotanical medicinal plants used by the people of District guna, Madhya Pradesh, India. Int J Life Sci Scienti Res 4(4):1880-1888

18. Reddy AM, Suresh Babu MV, Rao RR (2019) Ethnobotanical study of traditional herbal plants used by local people of Seshachalam Biosphere Reserve in Eastern Ghats, India. Her Polonica 65(1):40-54. https://doi.org/1 0.2478/hepo-2019-0006

19. Mipun M, Bhat NA, Borah D, Kumar $Y$ (2019) Non-timber forest products and their contribution to healthcare and livelihood security among the Karbi tribe in Northeast India. Ecol Process 8(1):41. https://doi.org/10.1186/ s13717-019-0194-4

20. Napagoda MT, Sundarapperuma T, Fonseka D, Amarasiri S, Gunaratna P (2019) Traditional uses of medicinal plants in Polonnaruwa District in North Central province of Sri Lanka. Scientifica 2019:1-11. https://doi.org/10.1155/2 019/9737302

21. Gangurde $A B$, Boraste SS (2012) Preliminary evaluation of Bauhinia racemosa Lam caesalpinaceae seed mucilage as tablet binder. Int J Pharm 2:80-83

22. Prakash A, Khosa RL (1976) Chemical studies on Bauhiniaracemosa. Curr Sci 45:705-707
23. El-Hossary GA, Selim MA, Sayed AE, Khaleel AE (2000) Study of the flavonoid content of Bassia muricata and Bauhinia racemosa. Bull Fac Pharm Cairo Univ 38:93-97

24. Sashidhara KV, Singh SP, Misra S, Gupta J, Misra-Bhattacharya S (2012) Galactolipids from Bauhinia racemosa as a new class of antifilarial agents against human lymphatic filarial parasite, Brugia malayi. Eur J Med Chem 50: 230-235. https://doi.org/10.1016/j.ejmech.2012.01.057

25. Md AR, Akhtar J, Sahabjada AM (2016) Evaluation of cytotoxic potential and apoptotic effect of a methanolic extract of Bauhinia racemosa Lam. against a human cancer cell line, HeLa. Eur J Integr Med 8(4):513-518

26. Anjaneyulu ASR, Reddy AVR, Reddy DSK (1984) Pacharin: a new dibenzo(2,36 ,7) oxepin derivative from Bauhinia racemosa Lamk. Tetrahedron 40(21): 4245-4252. https://doi.org/10.1016/S0040-4020(01)98799-X

27. Cox HE, Pearson D (1962) The Chemical analysis of foods. Chemical publishing Co Inc, New Work

28. Gawade B, Farooqui M (2018) Screening of phytochemicals and in vitro antidiabetic activity of Bauhinia racemosa LAM. leaves. Asian J Pharm Clin Res 11(6):190-193. https://doi.org/10.22159/ajpcr.2018.v11i6.24038

29. Anjaneyulu ASR, Reddy AVR, Reddy DSK (1986) Racemosol: a novel tetracyclic phenol from Bauhinia racemosa Lamk. Tetrahedron 42(9):24172420. https://doi.org/10.1016/0040-4020(86)80004-7

30. Rasheda K, Butnariu M (2014) Antimicrobial and antioxidant activities of Bauhinia racemosa Lam. and Chemical Content. Iran J Pharmaceut Res 13(3): 1073-1080

31. Prabhakar P, Gandhidasan R, Raman PV, Krishnasamy NR, Nanduri S (1994) De-Omethylracemosol: a tetracyclic 2,2-dimethylchroman from the roots of Bauhinia racemosa. Phytochem 36(3):817-818. https://doi.org/10.1016/ S0031-9422(00)89827-1

32. Mulik MB, Katekhaye SD, Laddha KS (2015) Quantification of $\beta$-amyrin in B. racemosa lam. flower buds using HPTLC. Indian Drugs 52:34-36

33. Aggarwal BB, Bhardwaj A, Aggarwal RS, Seeram NP, Shishodia S, Takada Y (2004) Role of resveratrol in prevention and therapy of cancer: preclinical and clinical studies. Anticancer Res 24(5A):2783-2840

34. De Feudis FV, Papadopoulos V, Drieu K (2003) Ginkgo biloba extracts and cancer: a research area in its infancy. Fundam Clin Pharmacol 17:405-417

35. Takeoka GR, Dao LT (2003) Antioxidant constituent of almond [Prunus dulcis (Mill.) D.A. Webb.] hulls. J Agric Food Chem 51:496-501

36. Banskota AH, Tezuka Y, Adnyana IK, Xiong Q, Hase K, Tran KQ, Tanaka K, Saiki J, Kadota S (2000) Hepatoprotective effect of Commbretum quadrangulare and its constituents. Biol Pharm Bull 23(4):456-460. https:// doi.org/10.1248/bpb.23.456

37. Neda G, Rabeta M, Ong M (2013) Chemical composition and anti-proliferative properties of flowers of Clitoriaternatea. Int Food Res J 20:1229-1224

38. Sunita A, Manju S (2017) Phytochemical examination and GC-MS analysis of methanol and ethyl acetate extract of Root and stem of Gisekia pharnaceoides Linn. (Molluginaceae) From Thar Desert, Rajasthan, India. Res J Pharm Biol Chem Sci 8(4):168-174

39. Adnan M, Chy NU, Mostafa Kamal ATM, Azad OK, Paul A, Uddin SB, Barlow JW, Faruque MO, Park CH, Cho DH (2019) Investigation of the biological activities and characterization of bioactive constituents of Ophiorrhizarugosavar. prostrata (D.Don) and Mondal Leaves through In Vivo, In Vitro, and In Silico Approaches. Molecules 24(7):1367. https://doi.org/10.33 90/molecules24071367

40. Bhat KPL, Kosmeder JW, Pezzuto JM (2004) Biological effects of resveratrol. Antioxid Redox Signal 3(6):1041-1064. https://doi.org/10.1089/15230860131 7203567

41. Saleem M, Murtaza I, Tarapore RS, Suh Y, Adhami VM, Johnson JJ, Siddiqui IA, Khan N, Asim M, Hafeez BB, Shekhani MT, Li B, Mukhtar H (2009) Lupeol inhibits proliferation of human prostate cancer cells by targeting betacateninsignaling. Carcinogenesis 30(5):808-817. https://doi.org/10.1093/ca rcin/bgp044

42. Khatua S, Pandey A, Biswas SJ (2016) Phytochemical evaluation and antimicrobial properties of Trichosanthesdioica root extract. J pharmacog phytochem 5(5):410-413

43. Babu S, Jayaraman S (2020) An update on $\beta$-sitosterol: A potential herbal nutraceutical for diabetic management. Biomed Pharmacother 131:110702. https://doi.org/10.1016/j.biopha.2020.110702

44. Conrado GG, Simplicio FG, Costa KRC, Rehder VLG, Espinar MF, Souza GO, Sampaio PTB (2015) Antibacterial activity and chemical compounds of leaves and branches of Protiumhebetatum. Rev Bras PI Med 17(4):865-874. https://doi.org/10.1590/1983-084X/14_123 
45. Melo CM, Morais TC, Tome AR, Brito GA, Chaves MH, Rao VS, Santos FA (2011) Anti-inflammatory effect of $a, \beta$-amyrin, a triterpene from Protium heptaphyllum, on cerulein-induced acute pancreatitis in mice. Inflamm Res 60(7):673-681. https://doi.org/10.1007/s00011-011-0321-x

46. Holanda Pinto SA, Pinto LM, Cunha GM, Chaves MH, Santos FA, Rao VS (2008) Anti-inflammatory effect of alpha, beta-amyrin, a pentacyclic triterpene from Protium heptaphyllum in rat model of acute periodontitis. Inflammopharmacology 16(1):48-52. https://doi.org/10.1007/s10787-007-1609-x

47. Vitor CE, Figueiredo CP, Hara DB, Bento AF, Mazzuco TL, Calixto JB (2009) Therapeutic action and underlying mechanisms of a combination of two pentacyclic triterpenes, alpha- and beta-amyrin, in a mouse model of colitis. Br J Pharmacol 157(6):1034-1044. https://doi.org/10.1111/j.1476-5381.2009. 00271.x

48. Da Silva KA, Paszcuk AF, Passos GF, Silva ES, Bento AF, Meotti FC, Calixto JB (2011) Activation of cannabinoid receptors by the pentacyclic triterpene $a$, $\beta$-amyrin inhibits inflammatory and neuropathic persistent pain in mice. Pain 152(8):1872-1887. https://doi.org/10.1016/j.pain.2011.04.005

49. Chicca A, Marazzi J, Gertsch J (2012) The antinociceptive triterpene $\beta$-amyrin inhibits 2-arachidonoylglycerol (2-AG) hydrolysis without directly targeting CB receptors. Br J Pharmacol 167(8):1596-1608. https://doi.org/10.1111/j.14 76-5381.2012.02059.x

50. Oliveira FA, Vieira-Junior GM, Chaves MH, Almeida FR, Santos KA, Martins FS, Silva RM, Santos FA, Rao VS (2004) Gastroprotective effect of the mixture of alpha- and beta-amyrin from Protium heptaphyllum: role of capsaicinsensitive primary afferent neurons. Planta Med 70(8):780-782. https://doi. org/10.1055/s-2004-827212

51. Oliveira FA, Chaves MH, Almeida FR, Lima RC, Silva RM, Maia JL, Brito GA, Santos FA, Rao VS (2005) Protective effect of alpha- and beta-amyrin, a triterpene mixture from Protium heptaphyllum (Aubl.) March. trunk wood resin, against acetaminophen-induced liver injury in mice. J Ethnopharmacol 98(1-2):103-108. https://doi.org/10.1016/j.jep.2005.01.036

52. Meena SK, Amita G, Sharma MC (2019) Biological importance of phytochemical constituents isolated from the genus Mesua. Int J Pharmacogn Phytochem Res 11(2):70-83

53. Jasemi SV, Khazaei H, Aneva IY, Farzaei MH, Echeverría J (2020) Medicinal plants and phytochemical for treatment of pulmonary hypertension. Front Pharmacol 11. https://doi.org/10.3389/fphar.2020.00145

54. Christensen LP (2009) Galactolipids as potential health promoting compounds in vegetable foods. Recent Pat Food Nutr Agric 1(1):50-58. https://doi.org/10.2174/2212798410901010050

55. Semalty A, Semalty M, Singh D, Rawat MSM (2012) Phyto-phospholipid complex of catechin in value added herbal drug delivery. J Incl Phenom Macrocycl Chem 73(1-4):377-386. https://doi.org/10.1007/s10847-011-0074-8

56. Mahajan RT, Chopda MZ (2009) Phyto-Pharmacology of Ziziphusjujuba Mill-a plant review. Phcog Rev 3(6):320-329

57. Ulusoy HG, Sanlier N (2019) A mini review of quercetin: from its metabolism to possible mechanisms of its biological activities. Crit Rev Food Sci Nutr 60(19):3290-3303. https://doi.org/10.1080/10408398.2019.1683810

58. Yang F, Song L, Wang H, Wang J, Xu Z, Xing N (2015) Quercetin in prostate cancer: Chemotherapeutic and chemopreventive effects, mechanisms and clinical application potential (Review). Oncol Rep 33(6):2659-2668. https:// doi.org/10.3892/or.2015.3886

59. Ganeshpurkar A, Saluja AK (2017) The pharmacological potential of Rutin. Saudi Pharm J 25(2):149-164. https://doi.org/10.1016/j.jsps.2016.04.025

60. Chen AY, Chen YC (2013) A review of the dietary flavonoid, kaempferol on human healthand cancer chemoprevention. Food Chem 138(4):2099-2107. https://doi.org/10.1016/j.foodchem.2012.11.139

61. Loeffler J, Stevens DA (2003) Antifungal drug resistance. Clin Infect Dis 36:31-41

62. Groll AH, Lumb J (2012) New developments in invasive fungal disease. Future Microbiol 7(2):179-184. https://doi.org/10.2217/fmb.11.154

63. Ali MS, Azhar I, Amtul Z, Ahmad VU, Usmanghani K (1999) Antimicrobial screening of some Caesalpiniaceae. Fitoterapia 70(3):299-304. https://doi. org/10.1016/S0367-326X(99)00015-5

64. Dahikar SB, Bhutada SA, Tambekar DH, Vibhute SK, Kasture SB (2011) In vitro antibacterial efficacy of solvent extracts of leaves of Bauhinia racemosa Lam. (Caesalpiniaceae) against enteric bacterial pathogens. Int J Pharm Sci Drug Res 3:32-34

65. World Health Organization (1985) Programme for control of diarrhoeal diseases, 5 th Programme Report, Geneva. WHO Bull 63:557-772

66. Pramila G, Jirekar DB, Farooqui M, Naikwade SD (2014) Preliminary phytochemical screening and antibacterial activity of Bauhinia racemosa leaves. Biosci Biotech Res Asia 11(3):1737-1740. https://doi.org/10.13005/ bbra/1578

67. Heinrich M, Appendino G, Efferth T, Fürst R, Izzo AA, Kayser O, Viljoen A (2020) Best practice in research-Overcoming common challenges in phytopharmacological research. J Ethnopharmacol 246:112230. https://doi. org/10.1016/j.jep.2019.112230

68. Chaimanee V, Thongtue U, Sornmai N, Songsri S, Pettis JS (2017) Antimicrobial activity of plant extracts against the honeybee pathogens, paenibacillus larvae and ascosphaera apis and their topical toxicity to apis mellifera adults. J Appl Microbiol 123(5):1160-1116. https://doi.org/10.1111/ jam.13579

69. Fan J, Liu X, Pan W, Douglas MW, Bao S (2020) Epidemiology of 2019 novel coronavirus diseases in gansu province, China. Emerg Infect Dis 26(6):12571265. https://doi.org/10.3201/eid2606.200251

70. Gupta M, Mazumder UK, Sambath Kumar R, Gomathi P, Rajeshwar Y, Kakoti V, Tamil Selven BB (2005) Anti-inflammatory, analgesic and antipyretic effects of methanol extract from Bauhinia racemosa stem bark in animal models. J Ethnopharmacol 98(3):267-273. https://doi.org/10.1016/j.jep.2005.01.018

71. Milan C, Hana C, Petko D, Maria K, Anton S, Antonín L (2010) Different methods for control and comparison of the antioxidant properties of vegetables. Food Contr 21:518-523

72. Prior RL, Wu XL, Schaich K (2005) Standardized methods for the determination of antioxidant capacity and phenolics in foods and dietary supplements. Agric Food Chem 53(10):4290-4302. https://doi.org/10.1021/ jf0502698

73. Heim KE, Tagliaferro AR, Bobilya DJ (2002) Flavonoid antioxidants: chemistry, metabolism and structure-activity relationships. J Nutr Biochem 13(10):572584. https://doi.org/10.1016/S0955-2863(02)00208-5

74. Kumar RS, Sivakumar T, Sunderam RS, Gupta M, Mazumdar UK, Gomathi P, Rajeshwar Y, Saravanan S, Kumar MS, Murugesh K, Kumar KA (2005) Antioxidant and antimicrobial activities of Bauhinia racemosa L. stem bark. Braz J Med Biol Res 38(7):1015-1024. https://doi.org/10.1590/S0100-879X2 005000700004

75. Dasgupta N, De B (2007) Antioxidant activity of some leafy vegetables of India: a comparative study. Food Chem 101(2):471-474. https://doi.org/10.1 016/j.foodchem.2006.02.003

76. Wang C, Wixon R (1999) Phytochemicals in soybeans: their potential health benefits. Inform 10:315-321

77. Luo XD, Basile MJ, Kennelly EJ (2002) Polyphenolic antioxidants from the fruits of Chrysophyllum cainito L. (star apple). J Agric Food Chem 50(6):13791382. https://doi.org/10.1021/jf011178n

78. Gupta M, Mazumder UK, Siva Kumar T, Gomathi P, Sambath Kumar R (2004) Antioxidant and hepatoprotective effects of Bauhinia racemosa against paracetamol and carbon tetra-chloride induced liver damage in rats. Iran J Pharmacol Ther 3(1):12-20

79. Williams DA, Lemke TL (2002) Parasitic infection- Helminthes. In: Foye's principal of medicinal chemistry, 5th edn. Lippincott William and Wilkins, New York

80. Kumar T, Alexander A, Ajazuddin DD, Khan J, Sharma M (2011) Investigation of in vitro anthelmintic activity of Bauhinia racemosa Linn. J Appl Pharm Sci 1:73-75

81. WHO (2009) Global programme to eliminate lymphatic filariasis. Wkly Epidemiol Rec 44(2):437-444

82. Gyapong JO, Kumaraswami V, Biswas G, Ottesen EA (2005) Treatment strategies underpinning the global programme to eliminate lymphatic filariasis. Expert Opin Pharmacother 6(2):179-200. https://doi.org/10.1517/14 656566.6.2.179

83. Bockarie MJ, Taylor MJ, Gyapong JO (2009) Current practices in the management of lymphatic filariasis. Expert Rev Anti-infect Ther 7(5):595-605 https://doi.org/10.1586/eri.09.36

84. Borikar VI, Jangde CR, Rekhe DS, Philip P (2007) Study of analgesic activity of Bauhinia racemosa lam in Rats. Vet World 2(4):135-136

85. Chandrasekar KS, Prasanna KS (2010) Lack of analgesic activity of petroleum ether extract of Bauhinia racemosa Lam in rats and mice. J Pharm Negat Results 1(1):22-23. https://doi.org/10.4103/0976-9234.68871

86. Subraya KC, Dananjaya SKP (2011) Hepatoprotective activity of Bauhinia racemosa Linn. Int Res J Pharm 2(3):218-220

87. Harborn JB (1979) Phytochemical methods, 2nd edn, p 112

88. Akhtar AH, Ahmad KU (1995) Anti-ulcerogenic evaluation of the methanolic extracts of some indigenous medicinal plants of Pakistan in aspirinulcerated rats. J Ethnopharmacol 46(1):1-6. https://doi.org/10.1016/03788741(94)01220-T 
89. Nirmal SA, Dhasade W, Laware RB, Rathi RA, Kuchekar BS (2011) Antihistaminic effect of Bauhinia racemosa leaves. J Young Pharm 3(2):129131. https://doi.org/10.4103/0975-1483.80301

90. Borikar VI, Jangde CR, Philip P, Rekhe DS, Atole SK (2009) Study of antipyretic activity of Bauhinia racemosa Lam in rats. Vet World 2:217-218

91. Prusty KB, Venkateshwar Rao J, Subudhi SK, Anitha Reddy P, Raj Kumar J (2012) Anti-hyperglycemic activity of extracts of leaves of Bauhinia racemosa Lamk (Family-Caesalpineaceae) on normal and aloxan-induced diabetic rats. Int J Pharm Res Allied Sci 1(4):94-99

92. Kumar V, Rathore K, Jain P, Ahmed Z (2017) Biological activity of Bauhinia racemosa against diabetes and interlinked disorders like obesity and hyperlipidemia. Clin Phytosci 3(1):7. https://doi.org/10.1186/s40816-0170044-9

93. Malik B, Malik M, Balakrishnan N, Suresh B (2014) Evaluation of larvicidal activity of the different extracts against important species of mosquito: Anopheles stephensi. J Parasitol Vector Biol 6:11-15

94. Palshetkar A, Pathare N, Jadhav N, Pawar M, Wadhwani A, Kulkarni S, Singh KK (2020) In vitro anti-HIV activity of some Indian medicinal plant extracts. BMC Complement Med Ther 20(1):69. https://doi.org/10.1186/s12906-020-2 $816-x$

95. Khaled R, Meng-TL LTZ, Yong TZ (2013) Anti-HIV-1 potential of B. racemosa Lam. (Caesalpiniaceae) and Phytochemical profile. Topclass J Herbal Med 2 95-102

96. Panche AN, Diwan AD, Chandra SR (2016) Flavonoids: an overview. J Nutr Sci 5:47

\section{Publisher's Note}

Springer Nature remains neutral with regard to jurisdictional claims in published maps and institutional affiliations.

\section{Submit your manuscript to a SpringerOpen ${ }^{\circ}$ journal and benefit from:}

- Convenient online submission

- Rigorous peer review

- Open access: articles freely available online

- High visibility within the field

- Retaining the copyright to your article

Submit your next manuscript at $\boldsymbol{\nabla}$ springeropen.com 